\title{
Cenozoic tectonic and thermal history of the Nenana basin, central interior Alaska: new constraints from seismic reflection data, fracture history and apatite fission-track analyses
}

\begin{tabular}{|c|c|}
\hline Journal: & Canadian Journal of Earth Sciences \\
\hline Manuscript ID & cjes-2016-0197.R1 \\
\hline Manuscript Type: & Article \\
\hline Date Submitted by the Author: & 08-Feb-2017 \\
\hline Complete List of Authors: & $\begin{array}{l}\text { Dixit, Nilesh; University of Alaska Fairbanks, Department of Geosciences; } \\
\text { University of Alaska Fairbanks, Geophysical Institute } \\
\text { Hanks, Catherine L.; University of Alaska Fairbanks, Department of } \\
\text { Geosciences; University of Alaska Fairbanks, Geophysical Institute } \\
\text { Rizzo, Alec; University of Alaska Fairbanks, Department of Geosciences; } \\
\text { University of Alaska Fairbanks, Geophysical Institute } \\
\text { McCarthy, Paul; University of Alaska Fairbanks, Department of } \\
\text { Geosciences; University of Alaska Fairbanks, Geophysical Institute } \\
\text { Coakley, Bernard J.; University of Alaska Fairbanks, Department of } \\
\text { Geosciences; University of Alaska Fairbanks, Geophysical Institute }\end{array}$ \\
\hline $\begin{array}{l}\text { Please Select from this Special } \\
\text { Issues list if applicable: }\end{array}$ & N/A \\
\hline Keyword: & Nenana basin, Interior Alaska, Transtensional basin, Strike-slip faulting \\
\hline
\end{tabular}


Cenozoic tectonic and thermal history of the Nenana basin, central interior Alaska: new constraints from seismic reflection data, fracture history and apatite fission-track analyses Nilesh Dixit ${ }^{1,2 *}$, ncdixit@alaska.edu,

Catherine Hanks ${ }^{1,2}$, clhanks@alaska.edu,

Alec Rizzo ${ }^{1,2}$, ajrizzo@alaska.edu,

Paul McCarthy ${ }^{1,2}$, pjmccarthy@,alaska.edu,

Bernard Coakley ${ }^{1,2}$, bjcoakley@alaska.edu.

1) Department of Geosciences, University of Alaska Fairbanks, PO Box 755780 Fairbanks, AK 99775.

2) Geophysical Institute, University of Alaska Fairbanks, P O Box 757320 Fairbanks, AK 9977.

* Corresponding author, Phone: (907) 978-5808. 


\begin{abstract}
The Nenana basin of interior Alaska forms a segment of the diffuse plate boundary between the Bering and North American plates and is located within a complex zone of crustalscale strike-slip deformation that accommodates compressional stresses due to oblique plate convergence to the south. The basin is currently the focus of new oil and gas exploration. Integration of seismic reflection and well data, fracture data and apatite fission track analyses with regional data improves our understanding of the tectonic development of this continental strike-slip basin. The Nenana basin formed during the Late Paleocene as a 13-km-wide halfgraben, affected by regional intraplate magmatism and localized crustal thinning across the Minto fault in south-central Alaska. The basin was uplifted and exhumed along this faulted margin in Early Eocene through to Late Oligocene time in response to oblique subduction along the southern Alaska margin. This event resulted in the removal of up to $1.5 \mathrm{~km}$ of Late Paleocene strata from the basin. Renewed rifting and subsidence during Early Miocene time widened the basin to the west resulting in deposition of Miocene nonmarine clastic rocks in reactivated and newly-formed extensional half-grabens. In Middle to Late Miocene time, left lateral strike-slip faulting was superimposed on this half-graben system, with rapid subsidence beginning in Pliocene time and continuing to the present-day. At present, the Nenana basin is in a zone of transtensional deformation that accommodates compressional stresses due to oblique plate convergence and allows tectonic subsidence by oblique-extension along major basin-bounding strike-slip faults.
\end{abstract}

Keywords: Nenana basin; transtensional basin; Interior Alaska; strike-slip faulting 


\section{Introduction}

Continental transform boundaries are often narrow zones of tectonic deformation commonly associated with a steeply-dipping strike-slip fault or a complex array of steep strikeslip faults which accommodate the relative plate motion (Mann 2007; Seeber et al. 2010). The geometry, type and magnitude of relative plate displacement along the transform fault strongly control the complex morphologies of transpressional basins and transpressional folds developing along a transform margin (Ben-Avraham 1992; May 1993; Aksu et al. 2000). Continental transform basins often record the tectonic history of the transform plate boundary and related mechanisms of slip along the faults in their sedimentary fill. Investigating the origins and evolutionary histories of these transform basins would constrain the tectonic development of the transform fault systems as well as the structural architecture and thermal histories of transform margins.

The Nenana basin is a prominent structure that overlies the eastern edge of a diffuse plate boundary between the Bering plate to the west and the North American plate to the east (Cross and Freymueller 2008) (Figure 1). The basin is located between two regional right-lateral strikeslip fault zones - the Denali fault system to the south and the Kaltag-Tintina fault system to the north (Figure 1) (Page et al. 1995; Ruppert et al. 2008; Tape et al. 2015; Dixit and Hanks 2015). The northern foothills fold-and-thrust belt (NFFB) lies to the south of the Nenana basin. It is the northernmost limit of active deformation from the Alaska Range orogenic belt (Lesh and Ridgway 2007; Bemis et al. 2012). Recent seismological studies indicate that a number of seismically-active NE-striking, left-lateral crustal-scale strike-slip faults cut through the Nenana basin and show poorly characterized surface scarps (Figure 1) (Frohman 2015; Tape et al. 2015). There is a general agreement that the Nenana basin formed as a consequence of extension along 
transtension-related deformation along these major, NE-striking faults. Recent studies address the present-day tectonic deformation style of the Nenana basin (Page et al. 1995; Van Kooten et al. 2012; Tape et al. 2015). However, the timing of faulting, the origin and evolution of the basin is speculative and poorly understood. In addition, determining the extent of tectonic deformation in the basin has been difficult due to lack of outcrop, limited exploration well data and scarcity of publicly available seismic reflection data. As a result, it has been difficult to develop a cohesive tectonic model of the evolution of the basin.

The Nenana basin is a promising hydrocarbon exploration area in interior Alaska and may hold as much as 250 million barrels of recoverable oil, up to 28 billion cubic meter of recoverable natural gas and up to 8 billion short tons of identified coal resources (Merritt 1986; Doyon 2015). A better understanding of tectonically-induced deformation, sediment accumulation and subsequent thermal regimes in the subsurface over time can constrain the relative timing of trap formation, hydrocarbon generation and migration within the basin (Hubbert 1953; Hunt 1996; Van Kooten et al. 2012).

This study investigates the phases of tectonic deformation of the Nenana basin by an integrated analysis of two-dimensional (2D) seismic reflection profiles, well data, surface fracture data and apatite fission track data. This integrated analysis was used to constrain the thermal history of the basin and illustrate how basin subsidence and uplift events influenced the thermal regime of the basin over time.

\section{Geological Background}

Central interior Alaska is dominated by two continental-scale, dextral strike-slip fault systems: the Denali and Kaltag-Tintina fault systems (Figure 1). The Denali fault is an active intraplate, dextral strike-slip fault that arcs through the Alaska Range. This fault accommodates 
dextral shear strain resulting from the oblique plate convergence to the south (Eberhart-Phillips et al. 2003; Matmon et al. 2006). The Denali fault is reported to have $350 \mathrm{~km}$ of right-lateral strike-slip displacement and it extends steeply through the crust to depths as deep as $\sim 30 \mathrm{~km}$ (Lanphere 1978; Fisher et al. 2007; Haeussler 2008). The Tintina fault is a steeply dipping dextral strike-slip fault that extends through central Alaska and separates deformed ProterozoicPaleozoic North American crustal rocks from accreted Yukon-Tanana Terrane rocks in our study area (Till et al. 2007). Murphy and Mortensen (2003) suggested at least $450 \mathrm{~km}$ of dextral displacement along the Tintina fault in Late Cretaceous or Early Paleocene time. Since Early Paleocene time, slip on the Tintina fault system has been minimal (Brogan et al. 1975). At its western end, the Tintina fault connects with the Kaltag fault through a set of splay faults (Till et al. 2007). To the south, the Alaska Range is a dextral transpressional orogen with north-vergent thrusting along the northern foothills fold-and-thrust belt and strike-slip faulting along the Denali fault (Haeussler 2008; Bemis et al. 2015). At present, the shallow oblique subduction and collision of the Yakutat microplate along the southern Alaska margin drives the dextral transpressional deformation across the Alaska Range (Figure 1) (Bemis and Wallace 2007; Carver et al. 2008; Haeussler 2008). To the north of the central Alaska Range, contractional deformation continues into the Nenana pull-apart and Tanana foreland basins (Ridgway et al. 2007; Dixit and Hanks 2015). Geologic and seismological evidence suggest that a pure shear zone exists between the Denali and Tintina fault systems, driven by N-S directed crustal shortening in response to oblique plate convergence to the south (Ratchkovski and Hansen 2002; Ruppert et al. 2008; Bemis et al. 2015). Active faults and several active seismic zones (e.g. Minto Flats Seismic Zone, Fairbanks Seismic Zone and Salcha Seismic Zone) across this zone 
suggest clockwise rotation of crustal blocks to accommodate N-S directed crustal shortening in the region (Figure 1) (Page et al. 1995; Bemis et al. 2015).

Two major seismically-active northeast-striking left-lateral strike-slip faults cut through the Nenana basin: the Minto fault in the southeast and an unnamed fault in the northwest (Fault 2 on Figure 2). These two faults and subsidiary faults have been referred to as the Minto Flats Fault Zone (MFFZ) (Tape et al. 2015). At present, the basin is subsiding due to on-going oblique-strike-slip (transtensional) movement along the major basin-bounding faults and possibly due to crustal loading along the northern foothills of the central Alaska Range (Lesh and Ridgway 2007; Dixit and Hanks 2015; Tape et al. 2015).

Various tectonic models have been proposed to explain the present-day structural setting of the Nenana basin. Based on shallow seismic reflection and residual Bouguer anomaly data, Van Kooten et al. (2012) and Doyon Limited (2015) proposed that the Nenana basin is an extensional half-graben or graben complex that was formed along the Minto Fault. In contrast, Tape et al. (2015) and Dixit et al. (2015) interpreted the Nenana basin as a transtensional pullapart basin situated between the two basin-bounding active left-lateral faults within the MFFZ (Figure 3).

Only four exploration wells have been drilled in the Nenana basin (Figures 2 and 3). Figure 4 outlines the stratigraphy of the basin encountered by the exploration wells. Proterozoic to Early Paleozoic Yukon-Tanana Terrane schist and Late Paleozoic Totatlanika schist underlies the Cenozoic non-marine sedimentary basin. The sedimentary fill of the Nenana basin includes: Late Paleocene sediments (Late Paleocene Formation), a Miocene sequence (Usibelli Group), a Pliocene sequence (Nenana Gravel), and Quaternary surficial deposits (Figure 4) (Merritt 1986; Frost et al. 2002; Van Kooten et al. 2012). The Usibelli Group, the Miocene coal-bearing 
sequence, is further subdivided into five different formations--the Healy Creek, Sanctuary, Suntrana, Lignite Creek and Grubstake formations. The major thermally mature to marginally mature source rocks of the Nenana basin occur in the Late Paleocene and Healy Creek formations (Figure 4) (Van Kooten et al. 2012, Dixit and Tomsich 2014).

\section{Data and Methods}

The dataset used in this study includes $2000-\mathrm{km}$-long two-dimensional seismic reflection profiles, borehole logs from four exploration wells and apatite fission track (AFT) data from four rock samples: two collected from the well cuttings of Nunivak 1 well and two samples from an outcrop along the eastern margin of the basin, near the town of Nenana (Figure 2).

\subsection{Well data}

Borehole logs and lithostratigraphy data from four exploration wells (Nenana 1, Totek Hills 1, Nunivak 1 and Nunivak 2) were used as control points to determine the subsurface geology of the basin (Figures 2 and 5) (AOGCC 2015; Doyon Limited 2015). The age assignments for the observed sedimentary units in Nunivak 1 and Nunivak 2 wells were based on palynomorph data collected from these exploration wells (Gerry Van Kooten, written communication 2014). In addition to subsurface stratigraphy, sonic and density logs were further used to establish well-to-seismic ties that allowed the stratigraphic correlation of key seismic reflectors.

Nunivak 1 well was selected to generate a representative one-dimensional tectonic subsidence history model for the basin (Figures $3 \mathrm{~b}$ and 5). Nunivak 1 was chosen because it: 1) shows good tectonic history (unconformities and well preserved sedimentary strata); 2) represents most of the stratigraphic sequences that are well documented in outcrop; 3) is drilled at a geographic location which samples the deeper area within the basin; and 4) has reasonable 
thermal history data needed to calibrate the subsidence history model. The burial history for this well was generated using BasinMod software program (Platte River Associates Inc.). BasinMod software program uses decompaction and backstripping techniques to estimate tectonic subsidence according to method of Steckler and Watts (1978). The main input parameters for the modeling included the ages and depths of each stratigraphic horizon. To generate a useful thermal history for this well, we considered the basal heat flow model published for the Nenana basin by Van Kooten and others (2012) and Dixit and Hanks (2015). Our burial history model is constrained by the subsurface stratigraphy at Nunivak 1 well and the observed present-day temperature data.

\subsection{Seismic Reflection Data}

The seismic reflection data available for this study include four 2D seismic reflection profiles approximately $2000-\mathrm{km}$-long. These profiles extend down to $4 \mathrm{sec}$ in two-way-travel time (TA02, TA03, TA04 and TA05; Figure 3). Three seismic transects (TA02, TA03 and TA04) are oriented northwest-southeast whereas one seismic transect is oriented northeastsouthwest, parallel to the structural trend observed in the region. This $2 \mathrm{D}$ seismic grid was acquired and processed by ConocoPhillips and was kindly provided for our research. More recently, Doyon Limited (2015) published a series of additional 2D and 3D seismic reflection profiles that were acquired during hydrocarbon exploration surveys in the Nenana basin. We integrated this more recent published seismic reflection data with the $2 \mathrm{D}$ seismic grid provided by ConocoPhillips to evaluate the subsurface geometry, timing of faulting and evolution of the Nenana basin. An integrated seismic interpretation was performed employing the IHS Kingdom Suite. Synthetic seismograms and depth-converted seismic horizons were used for the correlation of stratigraphic units encountered in the wells as well as to generate structural and isopach maps 
for the selected horizons. The lithological and stratigraphic information derived from the published well data was used to constrain the age and geological interpretation of individual units.

\subsection{Apatite Fission Track (AFT) Data}

Four samples were collected for an AFT analysis to evaluate the thermal history of the Nenana basin. Samples 1 and 2 were collected from well cuttings of Nunivak 1 well stored at the Geological Materials Center in Eagle River, Alaska (Dixit and Tomsich 2014) (Figure 5). Sample 1 was taken from the Late Paleocene sediments (depth interval of $2746 \mathrm{~m}-3359 \mathrm{~m}$ ) whereas Sample 2 was taken from the Miocene Usibelli Group sediments (depth interval of 1695 m- $2252 \mathrm{~m}$ ). Samples 1 and 2 are from the hanging wall of the Minto Fault. Sample 3 was collected from quartzite of the Yukon-Tanana Terrane exposed along the Parks Highway (Figure 2). Sample 4 was obtained from schist of the Yukon- Tanana Terrane located farther south, near the town of Nenana (Figure 2). Both samples are from the footwall of the Minto Fault.

All of the samples were sent to Apatite to Zircon Inc. (A2Z, Idaho) for AFT analysis. The detailed experimental procedures and principles of fission track analysis that are implemented by Apatite to Zircon Inc. are described in Donelick et al. (2005). We used the HeFTy software (Ketcham et al. 2007) to model the time-temperatures histories for each sample. Input parameters for the time-temperature modeling (inverse modeling) of each sample were the fission-track length distribution and the fission-track age with errors of $\pm 1 \sigma$. For every inverse model, additional timing constraints such as stratigraphic age, sample depth and present-day temperature were applied to honor the tectonic burial history of the basin. Each inverse model randomly generated (Monte Carlo approach) 10000 independent time-temperature paths and compared the modelled data with measured fission track data. The best-fit solution for each of 
the inverse models was based on a goodness of fit (GOF) value, in which 'good' and 'acceptable' fit to the measured data corresponded to GOF values of 0.5 and 0.05 , respectively. The best-fit time-temperature path (GOF close to 1) provided the most likely thermal history for a given sample in accordance with the measured data.

\subsection{Fracture Sampling and Calcite Twin Data}

In order to investigate the history of fracture formation at the basin scale, we collected fracture data that included fracture orientations (strike and dip), modes of deformation (opening or shearing), the presence or absence of fracture fill (calcite or quartz) and cross-cutting relationships in the outcrop of basement schist rocks of the Yukon-Tanana Terrane exposed near the town of Nenana (Figure 2). We used the linear scanline fracture survey method to measure the fracture attributes of each fracture (Priest 1993). Each scanline was set up normal to the strike of a particular fracture set identified at the outcrop. Based on the quality of exposed rocks, at least 25 fractures were measured for each fracture set for further statistical analysis.

At high temperatures and in the presence of reactive fluids, open fractures are completely filled with mineral precipitates such as calcite and quartz (Laubach 2003). The cemented fractures therefore record fluid migration pathways and can provide information on stress regimes active during fracturing filling. To examine the modes of deformation and temperature history of such fractures, we collected oriented rock samples containing well-preserved veins for thin section analysis. Petrographic thin sections (cut parallel as well as normal to the mineralized vein walls) for each of these samples were made by National Petrographic Services, Inc in Houston, Texas. We analyzed these thin sections to interpret vein composition, type of deformation and the direction of shear identified from crystal orientations. 
Mechanical e-twinning occurs in calcite crystals that are deformed at low temperatures $(<$ $300^{0} \mathrm{c}$ ) and under high shear stresses (Burkhard 1993). Thin twins in calcite generally dominate at temperatures below $170^{\circ} \mathrm{C}$ whereas above $200^{\circ} \mathrm{C}$, calcite exhibits thick twins (Ferrill et al. 2004). As a result, twin morphologies in calcite from vein fillings can be used to provide information about deformation temperature of a host rock. In this study, we used thin sections from each sample to further analyze twin thickness and extent of deformation within a vein. Resulting calcite twin morphologic interpretations were then integrated with the apatite fission track data in order to constrain the timing of fracture formation within the basin.

\section{Observations}

\subsection{Major depositional sequences and events}

We identified four major seismic sequences from synthetic seismic ties, unconformities and reflection character within Cenozoic strata of the Nenana basin. These include: 1) Proterozoic to Paleozoic seismic basement; 2) Paleocene syn-rift sequence; 3) Miocene syn-rift sequence; and 4) Pliocene and younger post-rift sequence (Figures 6 and 7).

\subsubsection{Proterozoic to Paleozoic Pre-Rift Seismic Basement}

An erosional unconformity marks the top of Proterozoic to Paleozoic metamorphic basement rocks of the Yukon-Tanana Terrane. This basement unconformity dips to the east from Nenana 1 well and to the southeast from Totek Hills 1 well and truncates against a faulted-block along the Minto Fault, near the town of Nenana (Figures 2, 3 and 5). We first interpreted the basement sequence along the basin margins on the seismic profiles and traced it further into the deeper sections of the basin.

The seismic reflection data did not provide a direct reflection at the top of metamorphic basement (Figures 6 and 7). Consequently, well logs, truncation patterns of seismic reflectors 
and upper crustal models of the Nenana basin were defined with the potential field data from gravity and magnetics (see Dixit and Hanks 2015). These data constrain our interpretation of the top of metamorphic basement within the basin (Figures 6 and 7). The interval velocities directly derived from the well data for our interpreted basement sequence are $4.5-5.3 \mathrm{~km} / \mathrm{s}$, and comparable to velocities of metamorphic bedrock in the Yukon-Tanana Terrane calculated from deep crustal seismic studies (4.9 km/sec; Brocher et al. 2004).

Two major northeast-striking, down-to-west faults bound the basin on the top-ofbasement structure (Fault 3 and Minto Fault; Figure 6). Both of these faults offset the basement unconformity and show $>1 \mathrm{~km}$ of the mean fault displacement. In map-view, the distance between the two northeast-striking basin-bounding faults generally increases to the north (Figure 3).

The top-of-basement structure map also illustrates the asymmetry of the Nenana basin (Figure 3). The basement surface deepens abruptly to $>5.5 \mathrm{~km}$ deep in the southeast, on the downthrown side of the Minto Fault. The top of basement shallows gradually westward where it is $1079 \mathrm{~m}$ at Nenana 1 well (Figure 3b). The basement on the upthrown side of the Minto Fault is exposed along the northeastern margin of the basin, near the town of Nenana (Figure 2).

\subsubsection{Paleocene and Older Synrift Sequence}

The palynomorph data collected from Nunivak 1 well suggests that $>305 \mathrm{~m}$ of Late Paleocene non-marine deposits overlie the seismic basement (Van Kooten et al. 2012, Gerry Van Kooten, written communication 2016). At the eastern basin margin, growth strata are evident in this sequence where high-amplitude, continuous seismic reflectors expand toward the major, northeast-striking faults that bound the basin (Figure 6). This Late Paleocene sequence thickens toward the east and above the deepest parts of the basin (Figure 6). The sequence also pinches 
out or thins towards the west, along the Nenana High and to the southwest, along the Totek Hills High (Figure 7). At the base of the sequence, seismic reflections onlap onto the irregular and gently sloping basement surface along the western and southwestern margins of the basin (Figures 6 and 7). The non-marine character of the sediments, thickening of strata against the major basement-involved faults and progressive onlap onto the underlying basement surface suggests active deposition of these sediments during growth of a normal fault-bounded basin, suggesting that this is a synrift sequence (Schlische 1991; Contreras et al. 1997).

\section{Early Eocene to Late Oligocene Unconformity}

At the top of the Late Paleocene sequence, an erosional unconformity truncates underlying seismic reflectors (Figures 6 and 7). This surface indicates that the underlying Paleocene sequence experienced a post-depositional exhumation. This unconformity is also evident as a hiatus on well logs (Nunivak 1 and Nunivak 2; Figure 5). To the west of Nenana High, the angular unconformity cannot be traced or identified on the seismic data (Figure 6).

\subsubsection{Miocene Synrift Sequence}

Seismic reflection ties to well control indicate that the sequence overlying the Late Paleocene Formation in Nunivak 1 and Nunivak 2 wells is Early Miocene to Late Miocene in age, based on the palynomorphs data (Gerry Van Kooten, written communication 2016) (Figure 5). This sequence marks the deposition of the fluvial and lacustrine coal-bearing rocks of the Miocene Usibelli Group (Van Kooten et al. 2012). On seismic reflection profiles, this sequence downlaps onto the underlying Early Eocene/Late Oligocene angular unconformity (Figures 6 and 7). This seismic sequence is characterized by high-amplitude, continuous reflections along the deeper sections of the basin and near the eastern basin margin (Figures 6 and 7). These seismic reflections become less continuous to discontinuous across the gently-sloping, western and 
southwestern basin margins. This discontinuity in seismic reflections suggests laterally heterogeneous lithologies or a fractured rock mass along these basin margins (Chopra and Marfurt 2008).

Based on the seismic reflection character, the Miocene sequence can be further divided into two sub-sequences: (1) a Lower Miocene sequence (including the Healy Creek and Sanctuary Formations), and (2) an Upper Miocene sequence (including the Suntrana Creek, Lignite Creek and Grubstake Formations) (Figure 4). Stratigraphically, the Lower Miocene sequence is a fining-upward trend that reflects a transition from a sand-rich fluvio-deltaic environment of the Healy Creek Formation to a silt-rich lacustrine environment of the Sanctuary Formation (Ridgway et al. 2007, Van Kooten et al. 2012). In the seismic reflection data, the two subsequences are separated by a subaerial unconformity. On seismic reflection profiles, Sanctuary Formation strata progressively onlap the top-of-Healy Creek surface along the hanging wall and indicate a continuous deepening of the basin (Figure 6). This Lower Miocene sequence thickens across the northeast-striking major faults (Fault 3 and Minto Fault) and suggests sedimentation coeval with the development of these faults (Figure 6).

The Upper Miocene sequence consists of extensive braided fluvial-deltaic sediments of the sand-rich Suntrana and Lignite Creek formations that transition upward into the silt-rich, lacustrine facies of the Grubstake Formation (Figure 4) (Ridgway et al. 2007; Van Kooten et al. 2012). On seismic profiles, this sequence onlaps the underlying Lower Miocene sediments towards the western and southwestern basin margins and also thickens against the northeasttrending major basin faults (Fault 3 and Minto Fault). Deposition of the Upper Miocene sequence, therefore, records a renewed period of basin subsidence. 
Locally, a set of northwest-striking negative flower structures are associated with syndeformational growth strata within the Upper Miocene sequence (Figure 6). These northweststriking faults generally cut through the basement surface, indicating continuation of basementinvolved oblique-extensional faulting in the basin.

\subsubsection{Pliocene to Quaternary Post-Rift Sequence}

The top of the Miocene Usibelli Group is well defined as an unconformity surface in both outcrop and in wells and is overlain by the Pliocene Nenana Gravel and Quaternary deposits (Figure 5). On seismic profiles, the Nenana Gravel downlaps basinward onto the Miocene unconformity surface (Figures 6 and 7). This sequence displays a poor seismic reflectivity and/or a lack of continuous stratigraphic reflectors in large parts of the basin. Much of the poor seismic resolution in this section could be due to unconsolidated, fractured or poorly-sorted sediments (Dixit and Tomsich 2014).

This sequence thickens towards the north and above the deepest section of the basin (Van Kooten at al. 2012; this study) and thins westward and southwestward along the margins of the basin (Figure 6). The surface exposures of the Miocene Usibelli Group and Neogene Nenana Gravel sediments near the Totek Hills High (Figure 2) suggest that the southwestward-thinning of Pliocene-Quaternary strata could be due to erosion during the uplift and exhumation of this region (Figure 7). Unlike older basin sequences, the observed thickness variations of Pliocene and younger strata were not controlled by any major basement-involved fault. This suggests filling of the basin in a post-rift setting.

\subsection{Burial history of Nunivak 1 Well}


In order to better understand the subsidence and thermal history of the Nenana basin, we evaluated the tectonic subsidence history of the Nunivak 1 well (Figure 8). The Nunivak 1 well was drilled on an intra-basement high in the Nenana basin.

Cenozoic strata encountered in Nunivak 1 well record three distinct phases of tectonic subsidence and a single phase of uplift in the area (Figure 8). Subsidence rates are calculated from inferred compacted sediment thicknesses, as interpreted from Nunivak 1 well data. At the Nunivak 1 well site, rapid tectonic subsidence $(\sim 0.24 \mathrm{~km} / \mathrm{Ma})$ occurred from Late Paleocene to Early Eocene and resulted in the deposition of more than $1829 \mathrm{~m}$ of the Late Paleocene sediments. This was interrupted by a major episode of basement uplift and exhumation in Early Eocene $(54.8 \mathrm{Ma})$ to Late Oligocene $(23.8 \mathrm{Ma})$ that eroded and removed as much as $1524 \mathrm{~m}$ of the Late Paleocene Formation strata. Renewed tectonic subsidence in the Miocene resulted in the deposition of $2012 \mathrm{~m}$ of Usibelli Group strata in gravelly braided streams to high-sinuosity mixed-load streams and lacustrine environments (Figure 8) (Buffler and Triplehorn 1976). The rate of basin subsidence in the Miocene $(\sim 0.11 \mathrm{~km} / \mathrm{Ma})$ appears to be much slower than that in the Late Paleocene $(\sim 0.24 \mathrm{~km} / \mathrm{Ma})$. Our burial history curves further suggest that tectonic subsidence accelerated during Pliocene time $(\sim 0.37 \mathrm{~km} / \mathrm{Ma})$ with the deposition of about $1372 \mathrm{~m}$ of Nenana Gravel deposits in gravelly braided streams and alluvial fans (Wahrhaftig 1987). The basin continued to subside rapidly until the present.

\subsection{Apatite Fission Track Analysis}

A fission-track age is mainly a function of fission track lengths and, for apatite, records the cooling history of the host rock from temperatures $<120^{\circ} \mathrm{C}$ (Green et al. 1989; Gallagher et al. 1998, Ketcham et al. 1999). Apatite fission track ages and fission track length data were determined for 4 samples (Table 1). Fission track ages obtained from these 4 samples fall 
between $41.4 \pm 7.8 \mathrm{Ma}$ and $7.79 \pm 3.5 \mathrm{Ma}$ (Table 1 and Figure 9). In general, the AFT ages decrease from west to east (Figure 2). Samples 1 and 2 collected from the Nunivak 1 well show the oldest AFT ages (Figure 2) while samples 3 and 4 from the exposed basement rocks in the footwall of the Minto fault have the youngest AFT ages. The observed AFT ages and track lengths indicate that all samples have experienced temperatures $>120^{\circ} \mathrm{C}$ and have been totally annealed in the past (Figure 9).

\subsubsection{Cooling History of Samples 1 and 2 from the Nunivak 1 Well}

The AFT age of $39.41 \pm 4.8$ Ma for Sample 1 from the Late Paleocene Formation of Nunivak 1 well is significantly younger than the formation age (Table 1; O'Sullivan 1999). Mean track lengths of $13.9 \pm 1.52 \mu \mathrm{m}$ for this sample are shorter than the standard, unannealed mean track length of $16.3 \pm 0.9 \mu \mathrm{m}$ (Gleadow et al. 1986). These two observations suggest that Sample 1 resided in the apatite partial annealing zone (PAZ, $120^{\circ} \mathrm{C}$ to $60^{\circ} \mathrm{C}$ ) for a significant time. The HeFTy inverse model solution for Sample 1 shows a goodness-of-fit (GOF) of 0.94 for the AFT age and 0.82 for the track length (Figure 9). This model suggests a bimodal thermal history with two distinct phases of rapid burial and subsequent heating - first in the Late Paleocene to Early Eocene and second during Early Miocene to present day, with an intervening phase of rapid cooling in the Middle Eocene to Late Oligocene.

Sample 2 is from the Miocene Usibelli Group penetrated by the Nunivak 1 well (Figure 5). Sample 2 has an AFT age of $41.40 \pm 7.8 \mathrm{Ma}$ which is significantly older than the depositional age of the Miocene Usibelli Group (Table 1). The older AFT age thus indicates that Sample 2 was clearly not completely reset and contains apatite fission tracks that are inherited from the provenance of sediments deposited (Gleadow et al. 1986). Sample 2 also yields longer mean track lengths $(14.28 \pm 1.18 \mu \mathrm{m})$ compared to Sample 1, indicating rapid cooling of the host rock 
through the PAZ at $58 \mathrm{Ma}-55 \mathrm{Ma}$. The HeFTy inverse model solution for Sample 2 indicates a GOF of 0.96 for the AFT age and 0.46 for the track length (Figure 9). The relatively lower GOF for the AFT track length could be due to fission tracks that are inherited from the provenance of sediments deposited and not reset completely (Gleadow et al. 1986; O'Sullivan 1999). The weighted-mean time-temperature solution for this inherited apatite sample suggests that most of the cooling occurred between $60 \mathrm{Ma}$ to $50 \mathrm{Ma}$. This sample was then rapidly buried and subsequently heated from surface temperature $\left(15^{0} \mathrm{C}\right)$ to about $65^{0} \mathrm{C}$ since the Pliocene (Figure 9).

\subsubsection{Cooling History of Samples 3 and 4 from the Outcrops}

Sample 3 is from basement rocks (mainly quartzite) of the Nenana Basin exposed along the Parks Highway and in the footwall of the NE-striking, basin-bounding Minto Fault (Figure 2). The observed AFT age of $28.35 \pm 4.1 \mathrm{Ma}$ for Sample 3 is much younger than the depositional age and is therefore reset completely (Gleadow et al. 1986) (Figure 9). Similar to Sample 2, Sample 3 shows a longer mean fission track length of $14.45 \pm 1.44 \mu \mathrm{m}$ which indicates rapid cooling of the host rock through the PAZ. The HeFTy inverse model for Sample 3 indicates a GOF of 0.98 for the AFT age and 0.99 for the track length (Figure 9). The weighted-mean time temperature path for Sample 3 further suggests that the initial cooling of Sample 3 through the PAZ $\left(120^{\circ} \mathrm{C}\right.$ to $\left.60^{\circ} \mathrm{C}\right)$ occurred from Early Oligocene to Early Miocene. A continuous, gradual cooling history of Sample 3 can be interpreted as being due to continuous uplift of the footwall of the Minto Fault along the eastern basin margin.

Sample 4 is also from the basement rocks (mainly schist) of the Nenana basin, located farther south of Sample 3, near the town of Nenana (Figure 2). This sample yielded a much younger pooled age of $7.8 \pm 3.5 \mathrm{Ma}$ and mean track length of $14.3 \pm 1.2 \mu \mathrm{m}$ (Figure 9). The 
younger fission track age and longer fission track length of this sample suggest that the sample was reset completely and then uplifted rapidly through the PAZ during the Late Miocene $(\sim 10$ Ma to $7 \mathrm{Ma}$ ). The inverse model solution for Sample 4 provides a GOF of 1 and 0.99 for the AFT age and track length distribution, respectively.

Overall, thermal histories for all four samples suggest that the area experienced temperatures in excess of $120^{\circ} \mathrm{C}$ during Late Paleocene time. Following an episode of maximum burial, cooling through the PAZ in the deeper parts of the basin occurred in Mid Eocene to Late Oligocene time, whereas along the eastern margin of the basin, rocks were uplifted and cooled through the PAZ during the Early Oligocene to Late Miocene. At present, Samples 1 and 2 are undergoing rapid burial and are situated within the PAZ along the hanging wall of the Minto Fault (Figure 2). In contrast, Samples 3 and 4 are undergoing rapid uplift and are situated above the PAZ, along the footwall of the Minto Fault. The difference in the observed cooling histories of Samples 3 and 4 suggests a progressive migration of footwall uplift southward along the eastern margin of the basin over time. Our hypothesis is consistent with the rotational block model proposed for the eastside Minto Fault by Frohman (2015).

\subsection{Analysis of Fracture Sets and Fracture Formation Chronology}

We identified four main fracture sets in the regional basement schist of the YukonTanana Terrane located at an outcrop near the town of Nenana, hereafter referred to as the 'Nenana outcrop' (Figure 2). Based on the statistical analysis of fracture orientations, modes of deformation and cross-cutting relationships, these fracture sets were distinguished based on relative age, orientation, mode of opening and fracture fill (Figure 10). All of these fracture sets are shear fractures and are filled with calcite and/or quartz. Each of the fracture sets is discussed in detail below. 


\subsubsection{Fracture Set (F1)}

Fracture set $\mathrm{F} 1$ consists of shear fractures that range in strike from $300^{\circ}$ to $320^{\circ}$ and have an average dip of $75^{\circ} \mathrm{SW}+/-30^{\circ}$ (Table 2). At the Nenana outcrop, all other fracture sets (sets F2 to F4) terminate against this fracture set (Figure 10). In thin section, set F1 fracture fill is composed largely of calcite with subsidiary quartz. Calcite crystals appear blocky to fibrous in shape, whereas secondary quartz crystals tend to be elongated and blocky. In thin sections that are parallel to vein walls, the calcite crystals are oriented at $40^{\circ}-50^{\circ}$ angles to the right $\left(91^{\circ} \mathrm{NE}\right)$ with respect to the vein wall and suggest right-lateral shear (Table 2). However, in thin sections that are normal to vein walls, the calcite crystals are oriented at $30^{\circ}$ angles to the left relative to the vein wall showing a dominant dip-slip motion. Combined slip vectors inferred from thin sections of set F1 therefore suggest that the veins in this fracture set exhibit a right-lateral shear displacement with a strong dip-slip component (Table 2). The NW-striking right-lateral transfer fault in the Nenana basin shows a similar average orientation to set F1 $\left(325^{0}\right.$ strike with dip of $70^{0}$ ). We therefore correlate set F1 to the NW-striking oblique-slip fault in the basin.

The morphology and thickness of the calcite twins in set F1 indicate that both thin (Type $\mathrm{I},<170^{\circ} \mathrm{C}$ ) and thick (Type II, 200-300 ${ }^{\circ} \mathrm{C}$ ) twins are present (Table 2). Under increasing strain at temperatures below $170{ }^{\circ} \mathrm{C}$, new thin twins form instead of widening existing twins (Ferrill et al. 2004). We therefore interpret that thick calcite twins in fracture set F1 were formed when the host rock was exposed to temperatures $>200^{\circ} \mathrm{C}$ whereas thin twins were locally developed within thick twins at lower temperatures $\left(<170{ }^{\circ} \mathrm{C}\right)$.

\subsubsection{Fracture Set (F2)}

Fracture set F2 is a set of en-echelon shear fractures with a strike of $240^{\circ}-260^{\circ}$ and an average dip of $73^{\circ} \mathrm{SE}+/-30^{\circ}$ (Table 2). At the Nenana outcrop, slickenfibres on F2 fracture 
surfaces show dominantly left-lateral motion. In some places, these fractures abut against and postdate, set F1 and cross-cut set F3 (Figure 10). We therefore interpret that the fractures in set F2 formed after set F1 and simultaneously with set F3.

In thin section, fracture set F2 consists of extensional veins filled dominantly with quartz and shear veins filled primarily with calcite. The calcite-filled veins show a strong sense of leftlateral shear motion (Table 2). In thin sections cut parallel to the vein wall, calcite crystal orientations show two distinct groups. Calcite crystals in the first group are oriented from $65^{\circ}$ $75^{\circ}\left(311^{\circ} \mathrm{NW}\right)$, while the ones in the second group range from $40^{\circ}-50^{\circ}\left(286^{\circ} \mathrm{NW}\right)$ in orientation with respect to the vein wall. In thin sections cut normal to the vein walls, calcite crystals are oriented both at $20^{\circ}$ and $40^{\circ}$ angles. As a result, combined slip vectors for set $\mathrm{F} 2$ show that the opening projection of calcite-filled veins has predominantly left-lateral shear sense with a strong dip-slip component.

Both thick (Type II) and thin (Type I) calcite twins were observed in all of the thin sections of shear veins in set F2 (Table 2). The calcite twins show signs of deformation with patchy and curved twins.

\subsubsection{Fracture Set (F3)}

The shear fractures in fracture set $\mathrm{F} 3$ range in strike from $340^{\circ}-360^{\circ}$ and have an average dip of $81^{\circ} \mathrm{E}+/-30^{\circ}$ (Table 2). In outcrop, these Mode II shear fractures show a right-lateral shear sense. This set clearly abuts against set F1 and crosscuts set F2 (Figure 10). F3 fractures are filled primarily with calcite with secondary quartz. In thin sections parallel to vein wall, calcite crystals appear to have grown at a $45^{\circ}-60^{\circ}$ angle $\left(\sim 125^{\circ}-140^{\circ} \mathrm{SE}\right)$ with respect to the vein wall $\left(\sim 170^{\circ}\right)$ (Table 2$)$. No dip-slip motion was observed across the veins. The crystal 
orientations therefore indicate that the calcite-filled veins in set F3 were forming and simultaneously deforming in a mainly right-lateral shear-related regime.

Thick (Type II) and thin (Type I) calcite twins are also present in all of the thin sections obtained for set F3 (Table 2).

\subsubsection{Fracture Set (F4)}

Fractures from set $\mathrm{F} 4$ range in strike from $200^{\circ}-220^{\circ}$ and have an average dip of $74^{\circ} \mathrm{NW}$ $+/-30^{\circ}$ (Table 2). In contrast to F3, these Mode II shear fractures show predominant left-lateral strike-slip deformation at the Nenana outcrop. In some places, this fracture set abuts against all of the older fracture sets (F1-F3) and hence postdates all (Figure 10). In addition, this is the only fracture set in which filled fractures show a crack-seal texture with calcite crystals appearing to have grown from previously precipitated calcite reflecting incremental strain over time (Durney and Ramsay 1973). Both calcite and quartz crystals appear to be oriented perpendicular to $\left(\sim 300^{\circ} \mathrm{NW}\right)$ and at $45^{\circ}-60^{\circ}\left(\sim 340^{\circ} \mathrm{NW}\right)$ with respect to the vein wall $\left(\sim 210^{\circ}\right)$, indicating predominant left-lateral strike-slip deformation in the veins (Table 2).

Most thin sections from set F4 fractures show both thick (Type II) and thin (Type I) calcite twins (Table 2). However, in some thin sections of fractures that abut on the older sets, only thin calcite twins (Type $\mathrm{I},<170^{\circ} \mathrm{C}$ ) are observed. The shear fractures in set $\mathrm{F} 4$ that exhibit only thin calcite twins are interpreted to be youngest in Nenana outcrop. In the Nenana basin, NE-striking strike-slip faults such as the Minto Fault have a similar average orientation $\left(40^{0} \mathrm{NE}\right)$ to set F4 and share a left-lateral shear sense. We interpret that the shear fractures in set F4 are related to these NE-striking strike-slip faults in the basin.

\section{Discussion}

\subsection{Implications for the Tectonic Evolution of the Nenana Basin}


In this study, we integrated the seismic stratigraphy interpretations with the available fission track and fracture data analyses to construct a structural model for the evolution of the Nenana basin that is consistent with all observational data. A schematic structural section that reflects all four stages of basin evolution is shown in Figure 11. This section is based on the seismic line TA-02 that extends from the town of Nenana in the southeast to the northwest across the basin (Figure 3).

\subsubsection{Late Paleocene Basin-scale Extension and Initiation of Graben System}

Seismic reflection data interpretations such as the progressive onlap of synrift strata and growth strata patterns suggest that the Nenana basin initiated as a structural half-graben in the Late Paleocene time (Figure 11a). Growth strata within the Late Paleocene sediments provide an upper age constraint on the initial rifting in the Nenana basin. The formation of this extensional system was dominated by localized early extensional rifting along the north-east striking, westward-dipping Minto Fault.

Based on the seismic and paleomagnetic data, the restored average strike direction for the Minto Fault during this time is approximately N13 ${ }^{0} \mathrm{E}$ (Wallace and Ruppert 2012; this study). This observation highlights a mean regional WNW-directed crustal extension across the Nenana basin in Late Paleocene (Figure 11). The presence of more than $1.5 \mathrm{~km}$ of locally-sourced lacustrine and fluvial deposits (Van Kooten et al. 2012, Doyon Limited 2015) in the Late Paleocene Formation further confirms that this rifting phase was initiated rapidly and occurred no later than Late Paleocene.

In the deeper parts of the basin, the thermal history of Sample 1 indicates rapid heating from temperatures less then $40^{\circ} \mathrm{C}$ to higher than $170^{\circ} \mathrm{C}$ associated with the rapid burial of sediments during the Late Paleocene rifting episode (Figure 9). Considering that the maximum 
vertical depth of burial of the Late Paleocene Formation in Nunivak 1 well was $2012 \mathrm{~m}$ after compaction during this time, then an estimated geothermal gradient of $66^{\circ} \mathrm{C} / \mathrm{km}$ would be required. The cooling histories of the basement AFT samples (Samples 3 and 4) located along the footwall of the Minto Fault are also consistent with our interpretation of regionally extensive high heat flow in the Late Paleocene time (Figure 9).

\subsubsection{Eocene to Oligocene Regional Uplift and Erosion of Late Paleocene Strata}

An erosional unconformity at the top of the Late Paleocene sequence in the basin suggests a significant uplift occurred during Eocene to Late Oligocene time and marked the end of the initial phase of rifting in the Nenana basin (Figure 11b). This unconformity is well documented in the wells located on basement highs and implies that the rift-shoulders of the graben were exposed from the beginning of Eocene time through Oligocene time.

Our AFT data also supports a regional uplift event in the Nenana basin during Early Eocene to Late Oligocene time (Figure 9). AFT data from Samples 1 and 2 are located in the deeper parts of the basin and record rapid cooling and exhumation in the excess of $0.7 \mathrm{~km} / \mathrm{Ma}$ beginning in Early to Mid Eocene time. This implies that the Minto Fault was reactivated as reverse fault with an approximately $1.5 \mathrm{~km}$ of vertical displacement along its hanging wall during Eocene uplift and exhumation event. Sample 3 from the Nenana outcrop shows that it was uplifted and exhumed beginning in Mid to Late Eocene time with a slower cooling rate of $3.33^{0} \mathrm{C} / \mathrm{Ma}$. However, time-temperature path for Sample 4 located $4 \mathrm{~km}$ farther to the south from Sample 3 suggests that this sample was still buried and/or experienced higher heat flows through the Eocene to Oligocene time. We therefore propose that the regional uplift and exhumation progressed northeastward on either side of the Minto Fault and towards the Yukon-Tanana Upland during this time. 


\subsubsection{Transition from Extensional to Transtensional Fault Regime during Miocene time}

During the early Miocene, the Nenana basin widened with the formation of a new halfgraben on western shoulder of the basin (Figure 11c). Renewed rifting and continued subsidence along major northeast-striking faults allowed the deposition of Lower Miocene sequence (including Healy Creek and Sanctuary formations) in both northeast-trending half-grabens (Figure 11c). The Lower Miocene sequence thickens against the Minto fault, suggesting that the Minto fault was reactivated and grew as a normal fault during this early Miocene rifting phase. The depositional settings for the Lower Miocene sequence indicate a transition from proximal braided river deposits of the Healy Creek Formation to lacustrine deposits of the Sanctuary Formation. In addition to the presence of growth strata, this transition suggests that tectonic subsidence due to slip on major graben-bounding faults accelerated during the Mid Miocene and mainly controlled the deposition of the Lower Miocene sequence in the basin.

As the rifting and basin subsidence continued into the mid- to late Miocene, deposition of the Upper Miocene sequence (including Suntrana Creek, Lignite Creek and Grubstake formations) continued along the northeast-striking faults within the graben system (Figure 11c). Stratigraphic thickness variations across northwest-striking faults and the presence of minor growth strata within negative flower structures associated with these faults suggest that NWstriking faults were reactivated as oblique-extensional (transtensional) transfer faults, accommodating left-lateral motion along major northeast-striking faults and driving subsidence locally during this phase of rifting.

AFT time-temperature curves for samples 1,2 and 3 indicate that these samples were outside the partial annealing zone (temperatures $<60^{\circ} \mathrm{C}$ ) during Early Miocene time (Figure 9). Based on the observed thickness of Miocene strata $(\sim 1707 \mathrm{~m})$ in Nunivak 1 well, samples 1 and 
2 located along the hanging wall of the Minto Fault show slow burial from the Early Miocene to Late Miocene at $\sim 0.1 \mathrm{~km} / \mathrm{Ma}$. In the eastern region, along the Nenana outcrop, Sample 3 shows slower cooling $\left(\sim 2.7^{0} \mathrm{C} / \mathrm{Ma}\right)$ associated with the exhumation of Yukon-Tanana Upland during the Miocene time (Brennan 2012; Frohman 2015). In contrast, Sample 4 located 4 km farther away, exhibits a phase of rapid cooling $23.7^{\circ} \mathrm{C} / \mathrm{Ma}$ in Late Miocene and suggests that the exhumation of Yukon-Tanana Upland was migrating to the south during this time. In addition, a correlation of calcite twins paleothermometry with fission track data from Sample 4 suggests that calcitefilled shear fractures in all fracture sets (F1 to F4) formed during Mid to Late Miocene time (Figure 12).

We interpret that the reactivation of pre-existing NW-striking faults in this time resulted in the formation of conjugate shear fractures of sets F2 and F3 corresponding to a NE-directed shortening. These fractures are overprinted by shear fractures of set F4 that contain thick calcite twins (Type II) and have the same average orientation as Minto Fault are interpreted to have formed as result of left-lateral strike-slip displacement along the Minto fault during this time.

\subsubsection{Pliocene to Present Day Development of Transtensional Pull-apart Basin}

Pliocene to present-day growth of the Nenana basin is characterized by a profound change in sediment transport directions marked by the deposition of Nenana Gravel and Quaternary sediments in northerly flowing river systems (Figure 11d) (Wahrhaftig et al. 1969; Ridgway et al. 2007).

The nature of faulting and changes in sedimentary thicknesses across the northwest- and northeast-striking faults during this phase are difficult to constrain due to poor seismic reflectivity in younger sections of the basin. However, AFT data (Figure 9) suggest that samples 1 and 2 in the basin were undergoing rapid burial $\left(\sim 37-58^{\circ} \mathrm{C} / \mathrm{km}\right)$ during this time whereas 
sample 3 and 4 situated along the footwall of Minto Fault are being rapidly uplifted at present. Presence of deformed thin calcite twins in all fracture sets (F1 to F4) identified in this study is consistent with our interpretation that the basement rocks along the footwall of Minto Fault were exhumed and deformed since the Pliocene and now are exposed at the Nenana outcrop. Some shear fractures in set F4 that abut on the older fracture sets and contain only thin calcite twins are interpreted to have formed since the Pliocene and continue to form at the present-day (Figure 12).

The present-day stress tensor of the Nenana basin as inferred from seismic and fracture data corresponds to a left-lateral strike-slip regime with the principal maximum horizontal stress axis, $\mathrm{S}_{\mathrm{Hmax}}$, oriented $\mathrm{N} 30^{0} \mathrm{E}$. The NE-striking faults in the basin are oriented $\mathrm{N} 40^{0} \mathrm{E}$ at the present-day and therefore lie oblique to the regional compression axis allowing transfer of a component of strike-slip from crustal shortening of the central Alaska Range in response to plate convergence. This implies a $17^{0}$ clockwise rotation of the stress-field in the Nenana basin since Late Paleocene (Figure 11d).

\subsection{Implications for the Regional Tectonic Setting of Central Interior Alaska}

The Nenana basin is located along a diffuse plate boundary between the Bering plate to the west and the North American plate to the east. The basin occupies a position on the foreland side of the northern Alaska Range thrust system (Figure 1). Regional dextral Tintina-Kaltag and Denali strike-slip fault systems that bound the basin to the north and south respectively, accommodate N-S crustal shortening driven by an oblique plate convergence to the south. Our study provides more detailed information on regional intra-plate stress fields that were present during the different phases of basin evolution. These stress regimes likely reflect the tectonic 
influence of regional structural features that were active during individual phases of basin development in central Alaska.

Paleocene time in central Alaska was dominated by an extensional tectonic regime and was largely marked by high geothermal gradients associated with widespread intra-plate magmatism related to Pacific-Kula slab window subduction, regional-scale strike-slip faulting along the Tintina fault system and local subsidence along basin-scale extensional faults (Bradley et al. 2003; Till et al. 2007). In our study, high geothermal gradients $\left(66^{\circ} \mathrm{C} / \mathrm{km}\right)$ and initiation of the Nenana extensional half-graben in the Late Paleocene is consistent with regional intra-plate crustal thinning and associated NW-oriented extension, extensive magmatism and high heat flow. Modern day tectonic settings that show elevated geothermal gradients $\left(40^{\circ} \mathrm{C} / \mathrm{km}\right.$ to $100^{\circ} \mathrm{C} / \mathrm{km}$ ) due to high regional heat flow occur in regions affected by ridge subduction and near trench magmatism (Groome and Thorkelson 2009; Benowitz et al. 2012).

The Eocene-Oligocene exhumation event was a regional event in central Alaska (Trop and Ridgway 2007; Dusel-Bacon et al. 2016). Our results suggest that this regional exhumation episode resulted in uplift and erosion of Paleocene and older sedimentary strata in the Nenana Basin with the formation of a basin-wide angular unconformity. Researchers have suggested a number of different explanations for this regional event, including far-field effects of oblique northwestward subduction of oceanic crust and the Resurrection-Kula spreading ridge (Bradley et al. 1993; Haeussler et al. 2003); major strike-slip movements along the Denali and Tintina fault systems (Plafker and Berg 1994; Ridgway et al. 2002; Roeske et al. 2003) and counterclockwise rotation of western and southwestern Alaska that was driven by Eurasia-North America convergence (Coe et al. 1985; Plafker 1987; Lonsdale 1988). The observed regional 
unconformity associated with the Eocene-Oligocene thermal cooling and uplift event in the Nenana basin could have been caused by any or all of these geologic processes in central Alaska Regional extension resumed during Late Oligocene- Early Miocene with deposition of the Lower Miocene sequence in half grabens within the Nenana basin. During this time, extensional displacement along NE-striking faults that form the basin's major boundaries progressively widened the basin to the west. This model requires major dextral-slip along the Denali and Tintina fault systems to drive NW-directed extension in the basin. Previous studies on central Alaska suggest that such large-scale dextral shear was observed along the Denali and Tintina fault systems during Oligocene through Early Miocene time (Nockleberg et al. 2000; Ridgway et al. 2002; Moore and Box 2016) and is consistent with previous interpretations of the plate reorganization between the Kula/Pacific oceanic plate and the North American continental margin across south-central Alaska (Wallace and Engebretson 1984; Lonsdale 1988).

The development of the Nenana basin from Middle Miocene through Late Miocene was marked by a change from dominantly extensional to a transtensional regime. During this episode of transtension, left-lateral strike-slip shear was superimposed on pre-existing NE-trending half grabens in the basin. The inferred sinistral transtension in the basin was coeval with continuation of NW-directed oblique convergence between the Pacific and North American plates and onset of shallow subduction of the Yakutat microplate beneath the southern Alaskan margin (Wallace and Engebretson 1984; Plafker et al. 1994; Miller et al. 2002). We interpret the initiation of a transtensional fault regime in the Nenana basin during this time as the product of oblique crustal shortening across NE-striking major crustal-scale faults due to plate convergence to the south.

Rapid exhumation and tectonic development of the northern foothills of the central Alaska Range occurred since the Early Miocene to present in response to the far field effects of 
continuing subduction of the Yakutat microplate beneath south-central Alaska (Benowitz et al. 2011; Brennan 2012). In our study, the high tectonic subsidence rates observed in the basin during Pliocene to recent time likely reflect the influence of this north-vergent thrusting along the actively uplifting Alaska Range; with basin subsidence mainly controlled by oblique slip on the major basin-bounding faults. This setting continues to the present day.

\subsection{Implications for the thermal maturity and hydrocarbon generation}

The Nenana basin may have significant hydrocarbon resource potential. A detailed understanding of the thermal history and tectonic development of the basin provides information on source rock maturity, timing of hydrocarbon trap formation and the present-day hydrocarbon generation potential of the basin. The burial and thermal history models developed in this study aid in the general understanding of the hydrocarbon potential of the Nenana basin and complement previous hydrocarbon studies on the basin.

Numerous authors have used Rock-Eval Pyrolysis and vitrinite reflectance data from well cuttings of Nunivak 1 well to evaluate the petroleum potential of the source rocks of the Nenana basin (Stanley and Lillis 2011, Van Kooten et al. 2012; Dixit and Tomsich 2014). These studies suggests that both Healy Creek and Paleocene Formation sediments in Nunivak 1 well have thermally-mature gas-prone coals with mean vitrinite reflectance ranging from 0.57 to $0.74 \% \mathrm{R}_{0}$ and organic-rich oil-prone shales with total organic content (TOC) up to about 61.32 wt.\%. Our results show that the source rocks of the Paleocene Formation in Nunivak 1 well first entered the early oil maturity zone in Late Paleocene time when they were buried to depths greater than 1.5 $\mathrm{km}$ and exposed to paleotemperatures significantly greater than the modern-day temperatures (Figure 8). However, subsequent uplift and erosion during Eocene-Oligocene time removed significant volumes of mature Paleocene source rocks and lowered the hydrocarbon generation 
potential of remaining strata by reducing temperature and overburden pressure, It is likely that the NE-striking faults were reactivated as reverse faults at this time, causing hydrocarbon leakage to the surface and further reducing the hydrocarbon storage capacity of the basin.

Hydrocarbon generation in the Early Miocene Healy Creek Formation source rocks began in the Mid Miocene time when the source rocks first entered into the early oil generation window (Figure 8). This was followed by rapid subsidence during the Pliocene and a corresponding increase in subsurface temperatures and pressures. At present, the source rocks of both the Early Miocene Healy Creek and Paleocene formations in Nunivak 1 well are in the main oil generation window and are likely sources of oil and gas accumulations in the basin. Our seismic-to-well ties suggest that thick fluvial sandstones with porosities ranging from $16 \%$ to $24 \%$ commonly occur in tilted fault blocks and within the Healy Creek and Suntrana formations of the Nenana basin (Van Kooten et al. 2012; Doyon Limited 2015). These Miocene reservoir rocks overlie thermally-mature hydrocarbon generating source rocks of the basin and could be the most important reservoir rocks in the basin. As inferred from seismic data, intra-formational shales in the Healy Creek Formation and siltstones of the Sanctuary and Grubstake formations pinch out against the basement highs and could further seal the reservoir sands against fault contacts (Figures 6 and 7). The observed growth strata and regional unconformities in the basin further indicate that the formation of NW- and NE-striking faults predates the Miocene to recent hydrocarbon generation and likely control formation of structural traps in the Miocene sandstone reservoirs. A good example of such faulted block structural traps within the Nenana basin is an intra-basinal high (Figure 1) that has been the focus of an extensive hydrocarbon exploration program in recent years (Doyon Limited 2015). 
The timing of fracture development and their orientation may have significant impact on the direction of hydrocarbon migration and trap integrity. Fractures observed in the Nenana outcrop (Table 2 and Figure 11d) indicate WNW directed crustal extension since Mid Miocene time and could suggest ENE-trending migration pathways from deeper source rocks charging overlying Miocene sandstone reservoirs within the faulted block traps since this time.

\section{Conclusions}

Integrated analysis of seismic reflection data, borehole logs and surface fracture data yield a model for the structural evolution of the Nenana basin. The burial history results were integrated with apatite fission track and calcite twinning thermometry data to further provide thermochronological constraints on the timing of deformation in the basin and to evaluate the petroleum source rock maturation. This integrated analysis reveals three distinct phases of rifting and an episode of regional uplift and exhumation since formation of the basin in Late Paleocene time. The results of our fission track analyses further confirm the episodes of maximum paleotemperature associated with rifting and cooling due to regional episode of uplift and exhumation. In addition to this, we identified four distinct fracture sets showing fractures of differing character (fracture strike and dip, modes of deformation and the nature of fracture fill) from the outcrop studies and tied them to the major faults in the basin. These fracture sets show evidence of different faulting mechanisms present within the basin and likely represent the state of stress in the region over time.

During Late Paleocene time, intraplate magmatism and subsequent extension formed and/or reactivated a series of normal faults in central Alaska (Till et al. 2007; Wallace and Ruppert 2012). The Nenana basin initiated as an extensional half graben along one of these extensional faults, the Minto Fault, during this time. Fault-controlled rapid tectonic subsidence 
$(\sim 0.24 \mathrm{~km} / \mathrm{Ma})$ and extension-related regional magmatism resulted in high heat flow with corresponding geothermal gradient of $\sim 66^{0} \mathrm{C} / \mathrm{km}$ in the basin. This first major paleothermal episode in the basin was coeval with the deposition of Late Paleocene source rocks. These source rocks entered the oil maturity window at shallow depths due to these increased temperatures during the Late Paleocene.

Beginning in the Early Eocene through Late Oligocene, central Alaska experienced regional-scale uplift and exhumation in response to oblique Resurrection-Kula ridge subduction and associated crustal-scale strike-slip faulting along major the Denali and Tintina fault systems (Trop and Ridgway 2007; Dusel-Bacon et al. 2016). This regional uplift and exhumation event resulted in the reactivation of the Minto Fault as a reverse fault and removal of up to $1.5 \mathrm{~km}$ of Late Paleocene strata from some parts of the Nenana basin. Apatite fission track analyses of all samples indicate rapid cooling through the PAZ $\left(120^{\circ} \mathrm{C}\right.$ to $\left.60^{\circ} \mathrm{C}\right)$ during this time. Uplift and erosion of significant volumes of mature source rocks in the basin at this time may have resulted in significant loss of hydrocarbons to the surface.

Plate reorganization between the Kula/Pacific oceanic plate and the North American plate during Miocene time caused a major change in stress field orientation across most of southern Alaska, including the Nenana basin (Wallace and Engebretson 1984; Lonsdale 1988). During the Mid to Late Miocene time, crustal shortening oblique to the major NE-striking basin-bounding faults superimposed a left-lateral shear on the pre-existing half-grabens in the basin. NW- and NE-striking faults were reactivated as oblique-extensional (transtensional) faults, further driving basin subsidence locally. Both Paleocene and Miocene source rocks were buried and subsequently subjected to increased temperatures that may have initiated hydrocarbon generation. During the Mid to Late Miocene time, fracture sets (F1 to F4) observed along the 
eastern margin of the basin were formed. Fission track data suggest that the hanging wall of the Minto Fault experienced basin subsidence $(\sim 0.1 \mathrm{~km} / \mathrm{Ma})$ whereas the footwall was uplifted. This uplift may have been related to the progressive southward exhumation of the Yukon-Tanana Upland during this time (Frohman 2015).

Starting in Pliocene time and continuing to today, central Alaska experienced northvergent crustal shortening in response to the far field effects of continuing subduction of the Yakutat microplate to the south. This resulted in uplift and exhumation of the central Alaska Range transpressional orogen (Benowitz et al. 2011; Brennan 2012). At present the northern part of the Nenana basin is undergoing WNW-directed extensional deformation along a step-over zone between major left-lateral strike-slip faults, further widening the basin in the north. The southern part of the basin is rapidly subsiding (geothermal gradients up to 37 to $58^{0} \mathrm{C} / \mathrm{km}$ ) in response to the crustal loading due to the Alaska Range to the south. The major source rocks of the basin are currently within the oil-generation window and likely sourcing a fresh hydrocarbon charge northwestward in updip structural traps that are controlled by the major fault systems in the basin.

\section{Acknowledgements}

This project was funded by the U.S. Air Force Office of Scientific Research (AFOSR), Award No. FA9550-11-1-0006. This project would not have been possible without access to the seismic data provided by Douglas Moore (ConocoPhillips Inc). We thank Carla Tomsich, Rachel Frohman and Wes Wallace for their field assistance and guidance during our field studies in the Nenana town and Suntrana Creek areas. We are greatly indebted to Kenneth Papp (Geologic Materials Center, Anchorage) for granting access to the well cuttings of Nunivak 1 and Nenana 1 
wells. Sincere thanks to Paul O'Sullivan (Apatite to Zircon, Inc) for fission track data analyses, Paul Walker (Weatherford Laboratories) for vitrinite reflectance analyses, and National Petrographic Inc. for preparing the thin sections. We are grateful to Tom Morahan, Gerry Van Kooten, Jim Mery, Carl Tape, Jeff Benowitz and Elizabeth Nadin for their constructive feedback. 


\section{References}

Alaska Oil and Gas Conservative Commission (AOGCC). 2015. Digital well history files, Available from http://doa.alaska.gov/ogc/publicdb.html [Accessed September, 2013].

Aksu, A.E., Calon, T.J., Hiscott, R.N., and Yasar, D. 2000. Anatomy of the North Anatolian fault zone in the Marmara Sea, Western Turkey: Extensional basins above a continental transform. GSA Today, 3-7.

Bemis, S. P. 2004. Neotectonic Framework of the North-Central Alaska Range Foothills, M.S. thesis, University of Alaska, Fairbanks, AK, USA.

Bemis, S.P., and Wallace, W.K. 2007. Neotectonic framework of the north-central Alaska Range foothills, in K. D. Ridgway, J. M. Trop, J. M. G. Glen, and J. M. O’Neill (Eds.), Tectonic growth of a collisional continental margin: Crustal evolution of southern Alaska. Geological Society of America Special Paper, 431:549-572.

Bemis, S.P., Carver, G.A. and Koehler, R.D. 2012. The Quaternary thrust system of the northern Alaska Range. Geosphere, 8(1):196-205, doi: 10.1130/GES00695.1.

Bemis, S.P., Welon, R.J., and Carver, G.A. 2015. Slip partitioning along a continuously curved fault: Quaternary geologic controls on Denali fault system partitioning, growth of the Alaska Range, and the tectonics of south-central Alaska, Lithosphere, L352.1, doi:10.1130/L352.1. 
Ben-Avraham, Z. 1992. Development of asymmetric basins along continental transform faults. Tectonophysics, 215: 209-220.

Benowitz, J. A., Layer, P. W., Armstrong, P., Perry, S., Haeussler, P. J., Fitzgerald, P. G., and VanLaningham, S. 2011. Spatial variations in focused exhumation along a continental scale strike-slip fault: The Denali fault of the eastern Alaska Range. Geosphere, 7(2): 455-467, doi:10.1130/GES00589.1.

Benowitz, J.A., Haeussler, P.J., Wallace, W.K., O’Sullivan, P.B., and Gillis, R.J. 2012. Cenozoic tectono-thermal history of the Tordrillo Mountains, Alaska: Paleocene-Eocene ridge-subduction, decreasing relief, and late Neogene faulting. Geochemistry Geophysics Geosystems, 13 (4): Q04009, doi:10.1029/2011GC003951.

Bradley, D.C., Haeussler, P., and Kusky, T. M. 1993. Timing of early Tertiary ridge subduction in southern Alaska. United States Geological Survey Bulletin, 2068: 163-177.

Bradley, D., Kusky, T., Haeussler, P., Goldfarb, R., Miller, M., Dumoulin, J., Nelson, S., and Karl, S. 2003. Geologic signature of early Tertiary ridge subduction in Alaska, in Session, V.B., Roeske, S.M., and Pavlis, T.L., eds., Geology of a transpressional orogen developed during ridge-trench interaction along the north Pacific margin. Geological Society of America Special Paper, 371: 19-49. 
Brennan, P.R.K. 2012. Lithospheric structure and geologic development of a collisional orogen: Insights from the central Alaska Range, Master's Thesis, Purdue University, Indiana, USA.

Brocher, T.M., Fuis, G.S., Lutter, W.J., Christensen, N.I., and Ratchovski, N.A. 2004. Seismic velocity models for the Denali fault zone along the Richardson Highway, Alaska, in 2002 Denali earthquake. Seismological Society of America Bulletin, Special Issue, 94: 85-106.

Brogan, G. E., Cluff, L.S., Korringa, M.K., and Slemmons, D.B. 1975. Active faults of Alaska, Tectonophysics, 29: 73-85.

Buffler, R.T., and Triplehorn, D.M. 1976. Depositional environments of the Tertiary coalbearing group, central Alaska, in Miller, T.P., ed., Recent and ancient sedimentary environments in Alaska, Proceedings of Symposium, April 2-4, Anchorage: Anchorage, Alaska Geological Survey, H1-H13.

Burkhard, M. 1993. Calcite twins, their geometry, appearance and significance as stress-strain markers and indicators of tectonic regime: a review. Journal of Structural Geology, 15: 351-368.

Carver, G.A., Bemis, S.P., Solie, D.N., and Obermiller, K.E. 2008. Active and potentially active faults in or near the Alaska Highway corridor, Delta Junction to Dot Lake, Alaska. Alaska Division of Geological \& Geophysical Surveys Preliminary Interpretive Report, 2008-3D: 1-32. 
Chopra, S., and Marfurt, K. J. 2008. Gleaning meaningful information from seismic attributes. First Break, 26: 43-53.

Coe, R.S., Globerman, B.R., Plumley, P.R., and Thrupp, G. 1985. Paleomagnetic results from Alaska and their tectonic implications, in Howell, D.G., ed., Tectonostratigraphic Terranes of the Circum-Pacific Region: Houston, Texas. Circum-Pacific Council for Energy and Mineral Resources, Earth Science Series, 1: 85-108.

Contreras, J., Scholz, C.H., King, G.C.P. 1997. A general model of rift basin evolution: constraints of first order stratigraphic observations. Journal of Geophysical Research, 102: 76737690.

Cross, R. S., and Freymueller, J. T. 2008. Evidence for and implications of a Bering plate based on geodetic measurements from the Aleutians and western Alaska. Journal of Geophysical Research, 113: B07405, doi:10.1029/2007JB005136.

Dixit, N. C., and Tomsich, C.S. 2014. Apatite fission track, magnetic susceptibility, and vitrinite reflectance analyses on cuttings from the Nunivak \#1 and Nenana \#1 wells, Alaska. Division of Geological \& Geophysical Surveys Geologic Materials Center Data Report, 422 (1): pp.891, doi:10.14509/27042.

Dixit, N.C., and Hanks, C. L. 2015. Cenozoic structural framework and tectono-sedimentary evolution of the southern Nenana basin, Alaska [abs]: Implications for conventional and 
unconventional hydrocarbon exploration. The American Association of Petroleum Geologists Annual Convention and Exhibition, Denver, Colorado, 3 June 2015.

Donelick, R. A., O'Sullivan, P. B., and Ketcham, R. A. 2005. Apatite fission-track analysis, in Reiners, P. W., and Ehlers, T. A., eds., Low-temperature thermochronology: techniques, interpretations, and applications, 49-94.

Doyon Limited. (2015). Alaska onshore rift basins, Nenana and Yukon Flats. Available from http://doyonoil.com/Content/pdfs/NenanaBasin3DSeismic.pdf [Accessed November, 2015].

Durney, D.W., and Ramsay, J.G. 1973. Incremental strains measured by syntectonic crystal growths. In: De Jong, K.A., Scholten, R. (Eds), Gravity and Tectonics, Wiley, New York, 67-96.

Dusel-Bacon, C., Bacon, C.R., O’Sullivan, P.B., and Day, W.C. 2016. Apatite fission-track evidence for regional exhumation in the subtropical Eocene, block faulting, and localized fluid flow in east-central Alaska. Canadian Journal of Earth Sciences, 53: 260-280, dx.doi.org/10.1139/cjes-2015-0138.

Eberhart-Phillips, D., Haeussler, P. J., Freymueller, J. T., Frankel, A. D. et al. 2003. The 2002 Denali fault earthquake, Alaska: a large magnitude, slip-partitioned event. Science, 300: 11131118. 
Ferrill, D.A., Morris, A.P., Evans, M.A., Burkhard, M., Groshong Jr., R.H., and Onasch, C.M. 2004. Calcite twin morphology: a low-temperature deformation geothermometer, Journal of Structural Geology, 26: 1521-1529.

Fisher, M. A., Pellerin, L., Nokleberg, W. J., Ratchkovski, N. A., and Glen, J. M. G. 2007. Crustal structure of the Alaska Range orogen and Denali fault along the Richardson Highway. Geological Society of America Special Papers, 431: 43-53, doi:10.1130/2007.2431(03).

Fletcher, H. 2002. Crustal Deformation in Alaska Measured using the Global Positioning system, Ph.D. thesis, University of Alaska Fairbanks, Fairbanks, Alaska, USA.

Frohman, R. A. 2015. Identification and evolution of tectonic faults in the greater Fairbanks area, Alaska, Master's thesis, University of Alaska Fairbanks, Fairbanks, Alaska, USA.

Frost, G.M., Barnes, D. F. and Stanley, R. G. 2002. Geologic and isostatic gravity map of the Nenana basin area, central Alaska. United States Geological Survey Geologic Investigations Series Map, 2543 (16), 2 sheets, scale 1:250,000.

Gallagher, K., Brown, R., and Johnson, C. 1998. Fission track analysis and its applications to geological problems, Annual Review of Earth and Planetary Sciences, 26: 519-572, doi:10.1146/annurev.earth.26.1.519. 
Gleadow, A.J.W., Duddy, I.R., Green, P.F., and Lovering, J.F. 1986. Confined fission track lengths in apatite: a diagnostic tool for thermal history analysis. Contributions to Minerology and Petrology, 94: 405-415.

Green, P.F., Duddy, I.R., Laslett, G.M., Hegarty, K.A., Gleadow, A.J.W., and Lovering, J.F. 1989. Thermal annealing of fission tracks in apatite: Quantitative modelling techniques and extension to geological timescales. Chemical Geology- Isotope Geoscience Section, 79: 155182.

Groome, W., and Thorkelson, D. 2009. The three-dimensional thermo-mechanical signature of ridge subduction and slab window migration. Tectonophysics, 464: 70-83, doi:10.1016/j.tecto.2008.07.003.

Haeussler, P.J., Bradley, D.C., Wells, R., and Miller, M.L. 2003. Life and death of the Resurrection plate: evidence for an additional plate in the northeastern Pacific in PaleoceneEocene time. Geological Society of America Bulletin, 115: 867-880.

Haeussler, P.J. 2008. An overview of the neotectonics of interior Alaska: Far- field deformation from the Yakutat microplate collision, in Freymueller, J.T., et al., eds., Active tectonics and seismic potential of Alaska. American Geophysical Union, Geophysical Monograph, 179: 269285. 
Hubbert, M. K. 1953. Entrapment of petroleum under hydrodynamic conditions. AAPG Bulletin, 37: 1954-2026.

Hunt, J.M. 1996. Petroleum Geochemistry and Geology. W. H. Freeman, New York, NY, USA, 2nd edition, pp. 743.

Ketcham, R.A., Donelick, R.A., and Carlson, W.D. 1999. Variability of fission-track annealing kinetics: Extrapolation to geological time scales. American Mineralogist, 84: 1235-1255.

Ketcham, R. A., Carter, A. C., Donelick, R. A., Barbarand, J., and Hurford, A. J. 2007. Improved modeling of fission-track annealing in apatite. American Mineralogist, 92: 799-810.

Koehler, R. D. 2013. Quaternary Faults and Folds (QFF). Alaska Division of Geological \& Geophysical Surveys Digital Data Series 3, Available from http://maps.dggs.alaska.gov/qff/ . doi:10.14509/24956.

Lanphere, M. A. 1978. Displacement history of the Denali fault system, Alaska and Canada. Canadian Journal of Earth Sciences, 15: 817 - 822 .

Laubach, S.E. 2003. Practical approaches to identifying sealed and open fractures. AAPG Bulletin, 87: 561-579. 
Lesh, M. E., and Ridgway, K. D. 2007. Geomorphic evidence of active transpressional deformation in the Tanana foreland basin, south-central Alaska, in K. D. Ridgway, J. M. Trop, J. M. G. Glen, and J. M. O’Neill (Eds.), Tectonic growth of a collisional continental margin: Crustal evolution of southern Alaska. The Geological Society of America Special Paper, 431: 573-593.

Lonsdale, P. 1988. Paleogene history of the Kula plate: offshore evidence and onshore implications. Geological Society of America Bulletin, 100: 733-754, doi: 10.1130/00167606(1988)1002.3.CO;2.

Mann, P. 2007. Global catalogue, classification, and tectonic origin of restraining and releasing bends on strike-slip faults, in Cunningham, D., and Mann, P., eds., Tectonics of strike- slip restraining bends. Geological Society of London Special Publication.

Matmon, A., Schwartz, D.P., Haeussler, P.J., Finkel, R., Lienkaemper, J.J., Stenner, H.D., and Dawson, T.E. 2006. Denali fault slip rates and Holocene-late Pleistocene kinematics of central Alaska. Geology, 34: 645-648.

May, S. R., Ehman, K. D., Gray, G. G., and Crowell, J. C. 1993. A new angle on the tectonic evolution of the Ridge basin, a "strike-slip" basin in southern California. Geological Society of America Bulletin, 105: 1357-1372. 
Merritt, R.D. 1986. Coal geology and resources of the Nenana Basin, Alaska. Alaska Division of Geological \& Geophysical Surveys, Public-data File, 086-74, pp.71.

Miller, M. L., Bradley, D. C., Bundtzen, T. K., and McClelland, W. 2002. Late Cretaceous through Cenozoic strike-slip tectonics of southwestern Alaska. Journal of Geology, 110: 247270, doi:10.1086/339531.

Moore, T.E., and Box, S.E. 2016. Time-slice maps showing age, distribution, and style of deformation in Alaska north of $60^{\circ}$ N. U.S. Geological Survey Open-File Report, 2016-1138, pp. 101, Available from http://dx.doi.org/10.3133/ofr20161138.

Murphy, D.C. and Mortensen, J.K. 2003. Late Paleozoic and Mesozoic features constrain displacement on Tintina fault and limit large-scale orogen-parallel displacement in the northern Cordillera [abs]. Geological Association of Canada-Mineralogical Association of CanadaSociety of Economic Geologists, Vancouver, pp. 151.

Nokleberg, W.J., Parfenov, L.M., Monger, J.W.H., Norton, I.O., Khanchuk, A.I., Stone, D.B., Scotese, C.R., Scholl, D.W., and Fujita, K. 2000. Phanerozoic tectonic evolution of the circumNorth Pacific. United States Geological Survey Professional Paper, 1626, pp.122.

O’Sullivan, P.B. 1999. Thermochronology, denudation and variations in palaeosurface temperature: a case study from the North Slope foreland basin, Alaska. Basin Research, 11(3): 191-204. 
Page, R. A., Plafker, G., and Pulpan, H. 1995. Block rotation in east-central Alaska: a framework for evaluating earthquake potential. Geology, 23 (7): 629-632.

Plafker, G. 1987. Regional geology and petroleum potential of the northern Gulf of Alaska continental margin, in Scholl, D.W., Grantz,A., and Vedder, J.G., eds., Geology and resource potential of the continental margin of western North America and adjacent ocean basins: Houston, Texas. Circum-Pacific Council for Energy and Mineral Resources, Earth Science Series, 6: 229-268.

Plafker, G., and Berg, H. C. 1994. Review of the geology and tectonic evolution of Alaska, in G. Plafker, and H. C. Berg (Eds.), The Geology of Alaska. Boulder, Colorado, Geological Society of America, The Geology of North America, G-1: 989-1021.

Priest, S.D. 1993. Discontinuity analysis for rock engineering. Chapman \& Hill, pp. 473.

Ratchkovski, N. A., and Hansen, R. 2002. New constraints on tectonics of interior Alaska: earthquake locations, source mechanisms, and stress regime. Bulletin of the Seismological Society of America, 92 (3): 998-1014.

Ridgway, K. D., Trop, J. M., Nokleberg, W. J., Davidson, C. M., and Eastham, K. R. 2002. Mesozoic and Cenozoic tectonics of the eastern and central Alaska Range: Progressive basin 
development and deformation in a suture zone. Geological Society of America Bulletin, 114: $1480-1504$.

Ridgway, K. D., Thoms, E. E., Layer, P. W., Lesh, M. E., White, J. M., and Smith, S. V. 2007. Neogene transpressional foreland basin development of the north side of the central Alaska Range, Usibelli Group and Nenana Gravel, Tanana Basin, in K. D. Ridgway, and others (Eds.), Tectonics Growth of a Collisional Continental Margin - Crustal evolution of southern Alaska. Geological Society of America Special Paper, 431: 507-547.

Rizzo, A. J. 2015. Natural fracture character and distribution adjacent to the Nenana basin, central Alaska, Master's thesis, University of Alaska Fairbanks, Fairbanks, Alaska, USA.

Roeske, S.M., Snee, L.W., and Pavlis, T.L. 2003. Dextral slip reactivation of an arc-forearc boundary during Late Cretaceous-Early Eocene oblique convergence in the northern Cordillera, in Sisson, V.B., Roeske, S.M., and Pavlis, T.L., eds., Geology of a transpressional orogen developed during ridge trench interaction along the North Pacific margin. Geological Society of America Special Paper, 371: 141-170.

Ruppert, N. A., Ridgway, K. D., Freymueller, J. T., Cross, R. S., and Hansen, R. A. 2008. Active tectonics of interior Alaska - Seismicity, GPS geodesy, and local geomorphology, in Freymueller, J. T. , Haeussler, P. J., Wesson, R. L., and Ekström, G. (Eds.), Active tectonics and seismic potential of Alaska: Washington, D.C. American Geophysical Union, Geophysical Monograph, 179: 109-133. 
Schlische, R.W. 1991. Half-graben basin filling models: new constraints on continental extensional basin evolution. Basin Research, 3: 123-141.

Seeber, L., Sorlien, C., Steckler, M., and Cormier, M.H. 2010. Continental transform basins: why are they asymmetric?. EOS -Transactions of the American Geophysical Union, 91: 29-31.

Stanley, R. G., and Lillis, P. G. 2011 Preliminary interpretation of Rock-Eval pyrolysis and vitrinite reflectance results from the Nunivak 1 well in the Nenana basin, central Alaska (Abs.), Society of Petroleum Engineers and Pacific Section, American Association of Petroleum Geologists, 87-88.

Steckler, M.S., and Watts, A.B. 1978. Subsidence of the Atlantic-type continental margins off New York. Earth and Planetary Science Letters, 41: 1-13.

Tape, C. H., Silwal, V., Ji, C., Keyson, L., West, M. E., and Ruppert, N. A. 2015. Transtensional tectonics of the Minto Flats fault zone and Nenana basin, central Alaska. Bulletin of the Seismological Society of America, 105 (4): 2081-2100.

Till, A.B., Roeske, S.M., Bradley, D.C., Friedman, R., and Layer, P.W. 2007. Early Tertiary ranstension-related deformation and magmatism long the Tintina fault system. Alaska.In: Till, A.B., Roeske, S.M., Foster, D.A., and Sample, J. (eds.) Exhumation and continental strike-slip 
fault systems. Geological Society of America Special Paper, 434: 233-264, doi:

10.1130/2007.2434(11)

Trop, J.M., and Ridgway, K.D. 2007. Mesozoic and Cenozoic tectonic growth of southern Alaska—A sedimentary basin perspective, in Ridgway, K.D., Trop, J.M., Glen, J.M.G., and O’Neill, J.M., eds., Tectonic growth of a collisional continental margin- crustal evolution of southern Alaska. Geological Society of America Special Paper, 431: 55-94.

Van Kooten, G. K., Richter, M. and Zippi, P. A. 2012. Alaska's interior rift basins: A new frontier for discovery, Oil and Gas Journal, pp.10.

Wahrhaftig, C., Wolfe, J. A., Leopold, E. B. and Lanphere, M. A. 1969. The coal-bearing group in the Nenana coal field, Alaska. United States Geological Survey Bulletin, 1274: 1-30.

Wahrhaftig, C. 1987. The Cenozoic section at Suntrana Creek, in M. L. Hill (Eds.), Geological Society of America, Cordilleran Section, Centennial Field Guide, 1: 445-450.

Wallace, W. K., and Engebretson, D.C. 1984. Relationship between plate motions and Late Cretaceous to Pa!cogene magmatism in southwestern Alaska. Tectonics, 3: 295-315.

Wallace, W.K., and Ruppert, N. 2012. Young tectonics of a complex plate boundary zone: Indentation, rotation, and escape in Alaska. American Geophysical Union fall meeting, San Francisco, CA, Abstract T14A-08. 
Wilson, F. H., Dover, J. H., Bradley, D. C., Weber, F. R., Bundtzen, T. K., and Haeussler, P. J. 1998. Geologic map of Central (interior) Alaska. U.S. Geological Survey Open-File Report, 98133-A, 62, 3 sheets.

\section{Figure Captions}

Figure 1. (Left) Simplified tectonic map showing regional tectonic framework of central interior Alaska and location of the Nenana basin relative to major active faults in the region. Faults are inferred from Bemis (2004), Koehler et al. (2013), Frohman (2015) and Tape et al. (2015). The Minto Flats Seismic Zone (MFSZ), the Fairbanks Seismic Zone (FSZ) and the Salcha Seismic Zone (SSZ). White box indicates the position of Figure 2. (Right) Simplified present-day tectonic model of the transtensional Nenana pull-apart basin (modified from Dixit and Hanks 2015). Horizontal velocity vectors relative to stable North America are inferred from the GPS velocities available for the region (Fletcher 2002).

Figure 2. (Top) Geologic map of central interior Alaska, showing the Cenozoic-age Nenana basin and exposed geology, including major lithologic units and regional fault systems. Dashed black lines indicate high-angle strike-slip faults inferred from active seismicity in the region as well as in surface outcrops in the Fairbanks area, (Ruppert et al. 2008; Frohman 2015; Tape et al. 2015). Quaternary thrust faults are shown as black lines with thrust symbols and define the northern limit of the Northern Foothills fold-and-thrust belt of the central Alaska Range (Bemis and Wallace 2007). Red box indicates the extent of seismic profiles used in this study (Figure 3; courtesy of ConocoPhillips). Map modified from Wilson et al. (1998). Stars indicate location of 
apatite fission track (AFT) samples collected from the wells (pink stars) and obtained from the Nenana outcrop (orange stars) used in this study (Rizzo 2015). (Bottom) 2016 Google Earth image showing the specific location of AFT samples collected along the George Parks Highway and at the Nunivak 1 well site.

Figure 3. Top of basement map for the Nenana basin showing the distribution of faults (solid black lines) and major structural features discussed in text. Map is in two-way travel time and based on the interpretation of $2 \mathrm{D}$ seismic profiles (blue lines) and published structural data by Dixit and Hanks (2015) and Doyon Limited (2015).

Figure 4. Generalized stratigraphy showing lithologies, depositional settings, sedimentary thickness, tectonic evolutionary phases and Cenozoic petroleum system of the Nenana basin (after Wahrhaftig 1987; Ridgway et al. 2007; Doyon Limited 2015). Fracture sets F1 to F4 are interpreted to have formed in the Mid Miocene to Late Miocene.

Figure 5. Lithostratigraphic correlation of exploration wells drilled in the Nenana basin. Location of the wells is shown in Figure 2. The Gamma Ray (GR) borehole logs display a broad lithological overview of strata present in each of the wells. Formation boundaries and ages were based on the published well data by Doyon Limited (2015) and palynomorphs data (Gerry Van Kooten, written communication 2016). Red arrows indicate the depth of samples collected from the well cuttings of Nunivak 1 well for fission-track dating (Dixit and Tomsich 2014). The sedimentary sequences are further correlated to tectonic deformation episodes that are recognized in the Nenana basin: syn-rift 1, syn-rift 2 and post-rift (See Section 4). 
Figure 6. Interpreted seismic profile TA-02 across the Nenana basin. See Figure 3 for the location of seismic profile TA-02. Seismic megasequences and formation boundaries are color coded and match colors of stratigraphic correlation shown in Figure 5.

Figure 7. Interpreted seismic profile TA-05 across the Nenana basin. See Figure 3 for the location of seismic profile TA-05. Seismic megasequences and formation boundaries are color coded and match colors of stratigraphic correlation shown in Figure 5.

Figure 8 . 1D burial history model of the Nunivak 1 well showing the relationship between subsurface depth of the key horizons, formation age and hydrocarbon generation windows. The burial history modeling was performed using BasinMod software developed by Platte River Associates. The model was further calibrated using formation thicknesses identified from Nunivak 1 data (AOGCC 2015), paleo-heat flow data estimated from fission track analyzes and published data by Van Kooten and others (2012), and thermal maturities published by Stanley and Lillis (2011) and Dixit and Tomsich (2014). Estimates of Eocene-Oligocene uplift and erosion are based on geohistory model of Nenana basin pseudowell published by Van Kooten and others (2012).

Figure 9. Time-temperature (t-T) histories calculated for samples 1 to 4 (see text for explanation). The t-T pathways were obtained from inverse modeling with HeFTy software (Ketcham et al. 2007). The main constraints on the possible t-T pathway for each sample include estimates of stratigraphic age, subsurface depth and present-day temperature at a given depth. 
The goodness-of-fit (GOF) is the fit between the observed and modelled data. Green and pink shaded areas mark envelopes of acceptable fit and good fit solutions (GOF $>0.5)$ respectively for each sample. As shown by modeling, Samples 1 and 2 are undergoing rapid burial and suggest ongoing basin growth and subsidence along the hanging wall of the Minto Fault. In constrast, Samples 3 and 4 are experiencing rapid cooling along the footwall of the Minto Fault and suggest a progressive migration of footwall uplift southward along the eastern margin of the basin.

Figure 10. Cross-cutting relationships of fracture sets F1, F2, F3 and F4 at the Nenana outcrop. (Left) Uninterpreted rock surface at the outcrop. (Right) Cross-cutting relationships of fracture sets F1 (red), F2 (yellow), F3 (white), and F4 (blue). Fracture sets F2, F3 and F4 terminate against set F1. Fracture set F1 is interpreted to be the earliest fracture set. Sets F2 and F3 commonly cross-cut each other and terminate on set F1. Set F4 terminates on all other fracture sets and is interpreted as the youngest fracture set.

Figure 11. Simplified tectonic evolution model of the Nenana basin: (A) Late Paleocene initiation of half-graben; (B) Mid Eocene to Late Oligocene regional uplift and erosion; (C) Early Miocene to Late Miocene transition from extensional to transtensional basin, (D) Pliocenepresent day transtensional pull-apart basin. See Section 5.0 for more detailed discussion. Compressional trends are inferred from paleomagnetic, seismic and fracture data studies (Wallace and Ruppert 2012; this study). 
Figure 12. Time-temperature path for Sample 4 located at the Nenana outcrop based on apatite fission track modeling. Stars show the proposed timing of fracture formation based on character and texture of calcite fracture fill. All of the fracture sets indicated they formed under shear conditions and contain calcite fill with Type II calcite twins, suggesting that the fractures were cemented and deformed during the early phase of transtension in Middle to Late Miocene time. Some fractures from set F4 that contain only Type I calcite twins and are interpreted as forming more recently, in Pliocene through present-day time. 


\begin{tabular}{|c|c|c|c|c|c|c|c|c|c|c|c|}
\hline Sample & $\begin{array}{l}\text { total } \\
\text { spots }\end{array}$ & $\begin{array}{c}\text { accepted } \\
\text { spots }\end{array}$ & sumNs & $\begin{array}{l}\text { [U]m } \\
\text { ppm }\end{array}$ & $\begin{array}{c}\text { [Th]m } \\
\text { ppm }\end{array}$ & $\begin{array}{c}\text { [Sm]m } \\
\text { ppm }\end{array}$ & $\begin{array}{c}\text { pooled } \\
\text { age }\end{array}$ & $\begin{array}{l}\text { Mean Track } \\
\text { Length }(\mu \mathrm{m})\end{array}$ & $\begin{array}{c}\text { Std. dev } \\
(\mu \mathrm{m})\end{array}$ & $\begin{array}{r}95 \%- \\
\text { CI }\end{array}$ & $95 \%+C I$ \\
\hline Sample 1 & 40 & 20 & 365 & 27.24 & 108.47 & 66.73 & 39.41 & 13.98 & 1.52 & 4.25 & 4.76 \\
\hline Sample 2 & 40 & 33 & 604 & 17.62 & 22.82 & 68.31 & 41.40 & 14.29 & 1.18 & 6.54 & 7.76 \\
\hline Sample 3 & 40 & 24 & 245 & 15.06 & 39.43 & 75.37 & 28.35 & 13.72 & 1.44 & 3.57 & 4.09 \\
\hline Sample 4 & 40 & 10 & 11 & 11.82 & 10.56 & 33.36 & 7.79 & 14.27 & 1.17 & 3.54 & 6.4 \\
\hline
\end{tabular}

Table 1. Apatite fission track data for the Nenana basin samples. 


\begin{tabular}{|c|c|c|c|c|c|c|}
\hline \multirow{2}{*}{ Set } & \multirow{2}{*}{ Orientation } & \multicolumn{2}{|c|}{ Fracture Character } & \multirow{2}{*}{$\begin{array}{l}\text { Sense of Motion } \\
\text { (Slip Vector) }\end{array}$} & \multirow{2}{*}{$\begin{array}{l}\text { Thin Section Analysis } \\
\text { (Parallel to the Strike) }\end{array}$} & \multirow{2}{*}{$\begin{array}{l}\text { Thin Section Analysis } \\
\text { (Parallel to the vein) }\end{array}$} \\
\hline & & Outcrop & Thin Section & & & \\
\hline F1 & & $\begin{array}{l}\text { - Shear fractures } \\
\text { - Right-lateral shear } \\
\text { - In basement schist }\end{array}$ & $\begin{array}{l}\text { - Quartz with secondary } \\
\text { calcite } \\
\text { - Right-lateral crystals angled } \\
\text { at } 40^{\circ}-50^{\circ} \text { alony strike } \\
\text { - Crystals are angled at } 30^{\circ} \\
\text { along dip } \\
\text { - Type I and Type II } \\
\text { calcite twins present }\end{array}$ & $\begin{array}{l}\text { - Strike: } 300^{\circ}-325^{\circ} \\
\text { - Average dip: } 75^{\circ} \pm 30^{\circ} \mathrm{SW} \\
\text { - Dominantly dip-slip with } \\
\text { right-lateral component } \\
\text { - Slip vector }>40^{\circ},<80^{\circ} \mathrm{SW}\end{array}$ & & (a) \\
\hline F2 & & $\begin{array}{l}\text { - Shear fractures } \\
\text { - Left-lateral shear } \\
\text { - In basement schist }\end{array}$ & $\begin{array}{l}\text { - Quartz and calcite veins } \\
\text { - Right-lateral crystals angled } \\
\text { at } 65^{\circ}-70^{\circ} \text { and } 40^{\circ}-50^{\circ} \text { along } \\
\text { strike } \\
\text { - Crystals are angled at } 30^{\circ} \text { to } \\
70^{\circ} \text { along dip } \\
\text { - Type I and Type II } \\
\text { calcite twins present }\end{array}$ & $\begin{array}{l}\text { - Strike: } 240^{\circ}-260^{\circ} \\
\text { - Average dip: } 73^{\circ} \pm 30^{\circ} \mathrm{SE} \\
\text { - Dominantly dip-slip with } \\
\text { left-lateral component } \\
\text { - Slip vector }>40^{\circ},<80^{\circ} \mathrm{SE}\end{array}$ & & Dip of vein: 6995E \\
\hline F3 & & $\begin{array}{l}\text { - Shear fractures } \\
\text { - Right-lateral shear } \\
\text { - In basement schist }\end{array}$ & $\begin{array}{l}\text { - Quartz and calcite veins } \\
\text {-Right lateral crystal } \\
\text { arrangement along strike } \\
\text { - Type I and Type II } \\
\text { calcite twins present }\end{array}$ & $\begin{array}{l}\text { - Strike: } 340^{\circ}-360^{\circ} \\
\text { - Average dip: } 81^{\circ} \pm 30^{\circ} \mathrm{E} \\
\text { - Dominantly right-lateral } \\
\text { with no dip-slip } \\
\text { component } \\
\text { - Slip vector N/A }\end{array}$ & & \\
\hline F4 & $\sqrt{ } \int$ & $\begin{array}{l}\text { - Shear fractures } \\
\text { - Left-lateral shear } \\
\text { - In basement schist }\end{array}$ & $\begin{array}{l}\text { - Quartz and calcite veins } \\
\text { - Left lateral crystal } \\
\text { arrangement along strike } \\
\text { - Type I and Type II } \\
\text { calcite twins present }\end{array}$ & $\begin{array}{l}\text { - Strike: } 200^{\circ}-220^{\circ} \\
\text { - Average dip: } 74^{\circ} \pm 30^{\circ} \mathrm{NW} \\
\text { - Dominantly left- lateral with } \\
\text { no dip-slip } \\
\text { component } \\
\text { - Slip vector N/A }\end{array}$ & 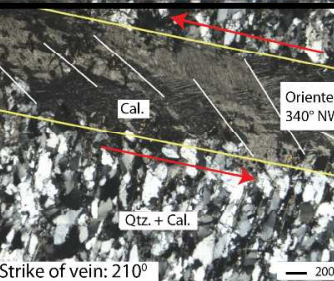 & \\
\hline
\end{tabular}

Table 2. Results of fracture analyses showing the orientations and characteristics of fracture sets F1 to F 4. 


\section{Regional Tectonic Setting of Central Alaska}

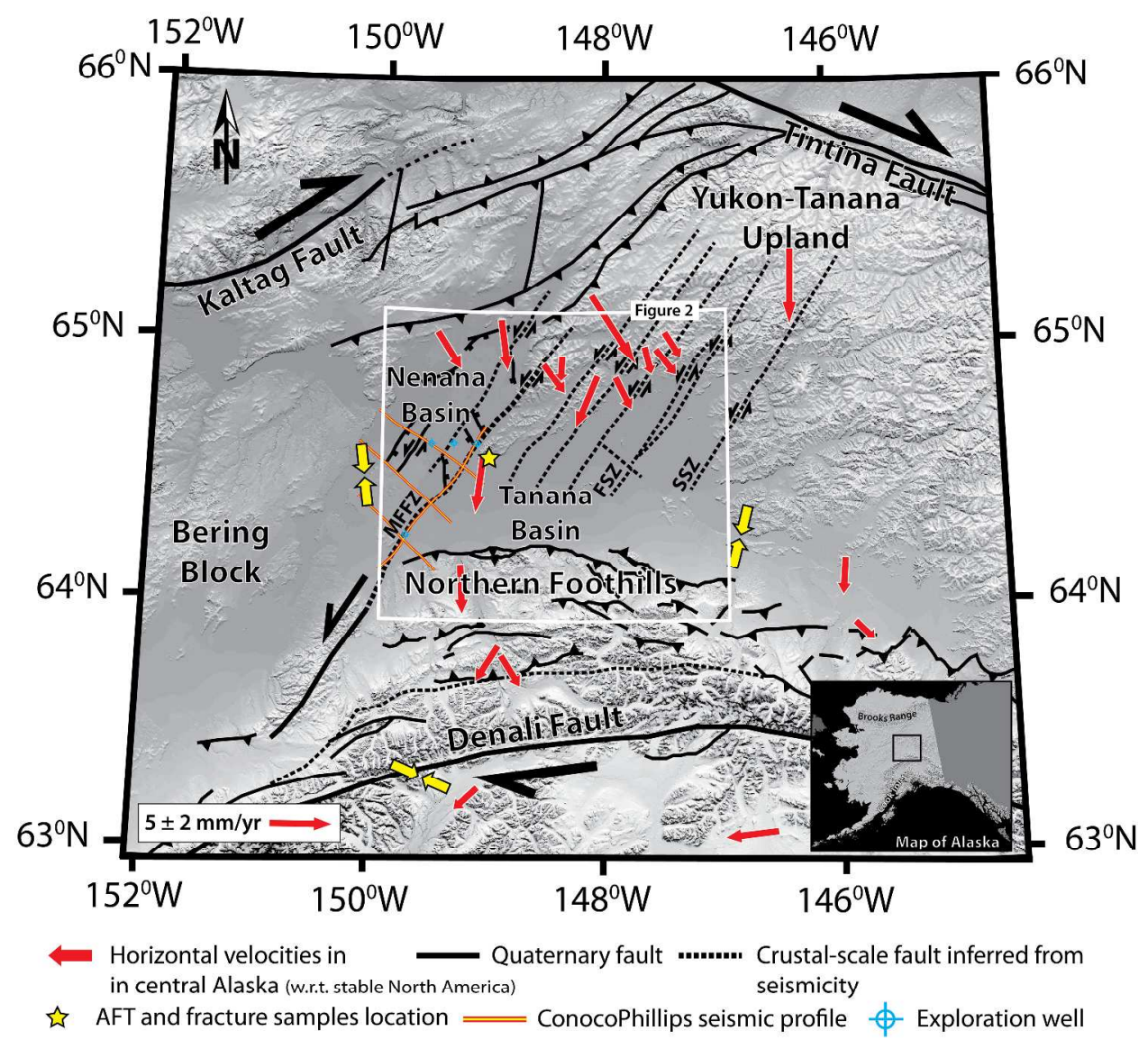

\section{Nenana Basin Configuration}

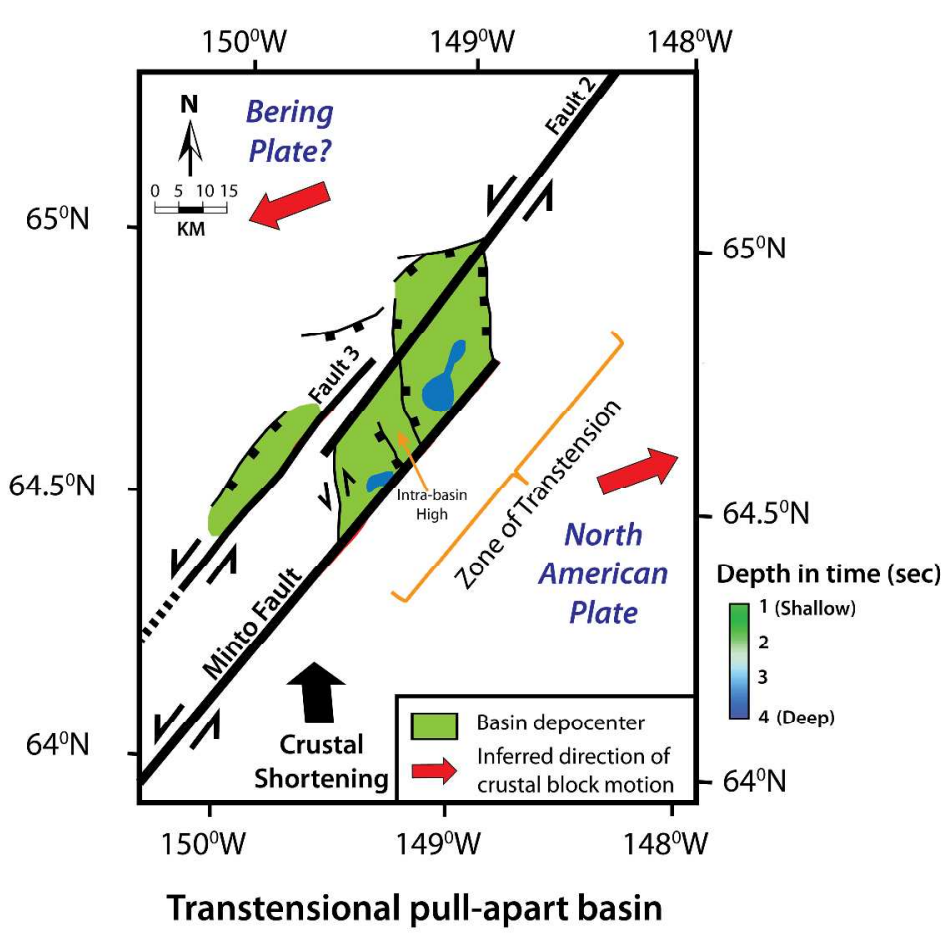




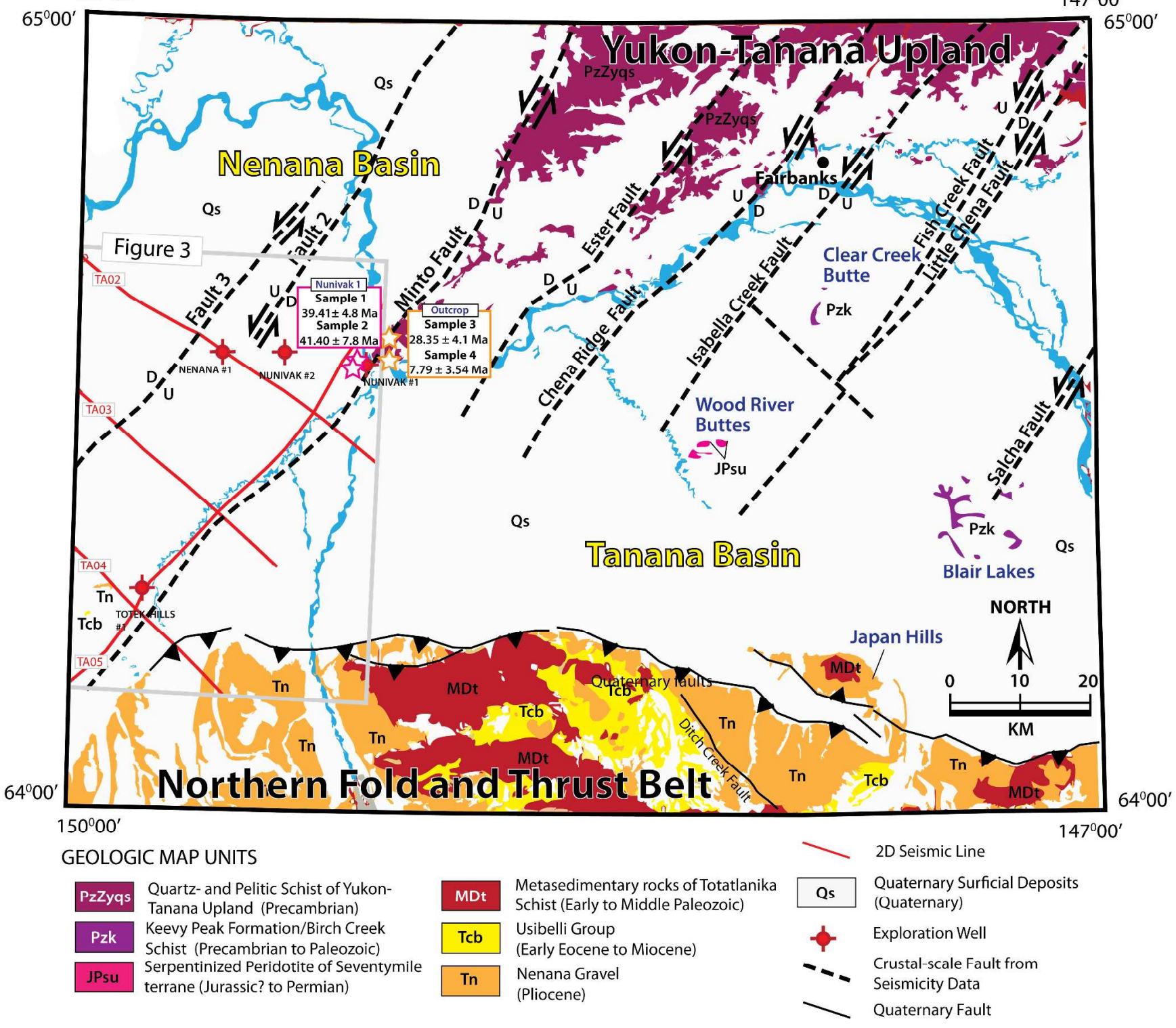




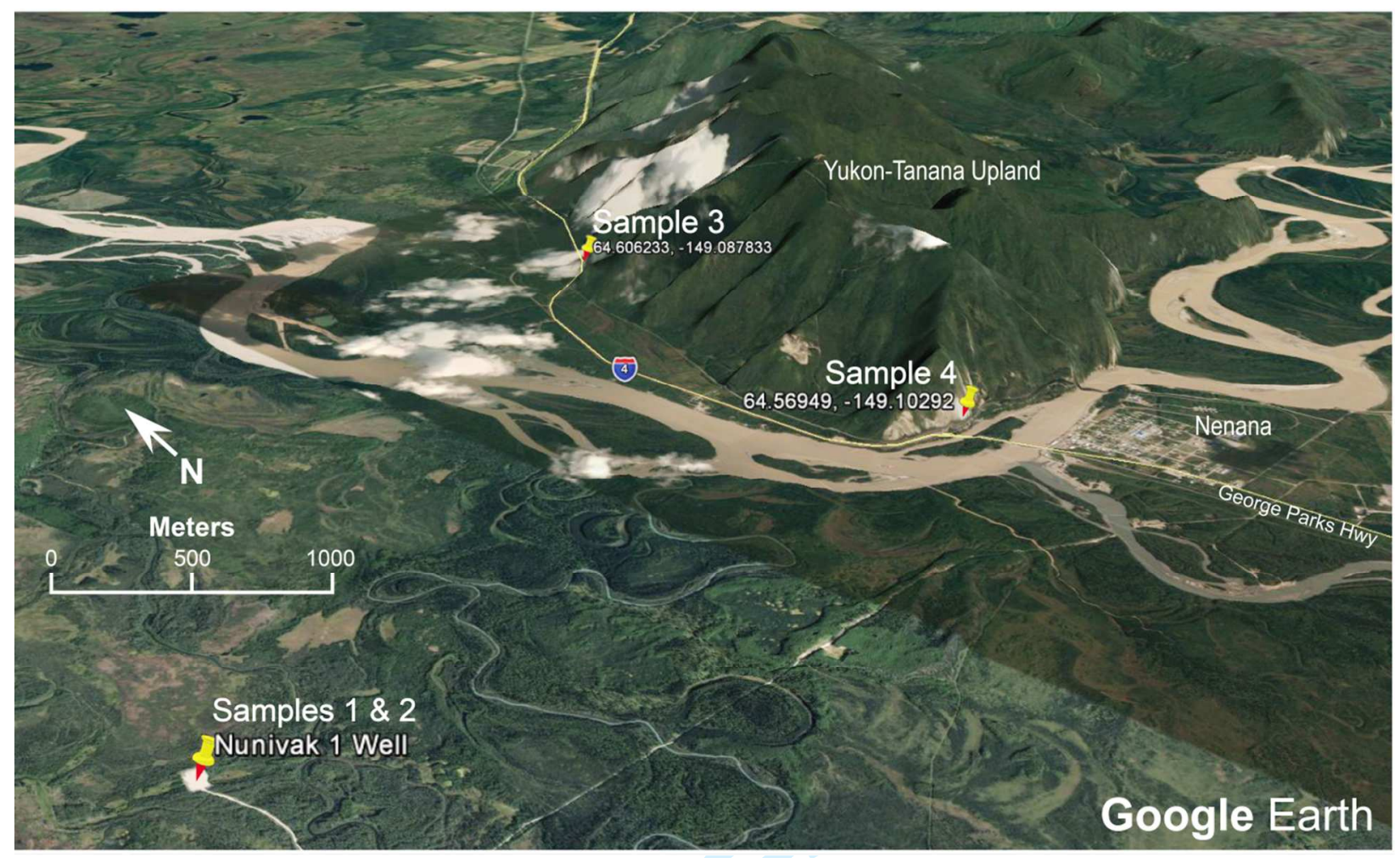




\section{Top of Seismic Basement}

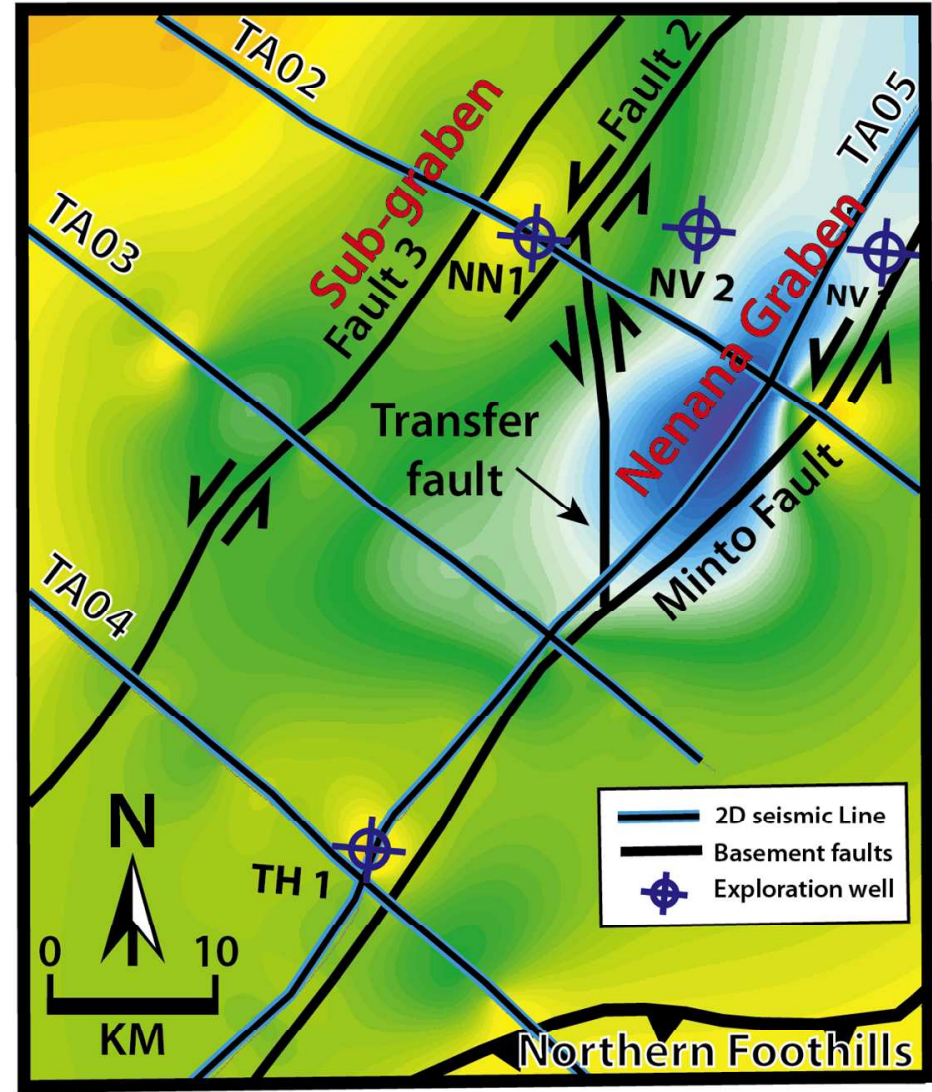

Basement Depth (TWT)

$0 \mathrm{sec}(0 \mathrm{~m})$

$2 \sec (3048 \mathrm{~m})$

$4 \sec (5640 \mathrm{~m})$

Abbreviations

TH1 Totek Hills 1

NN1 Nenana 1 NV Nunivak $1 \quad$ NV2 Nunivak 2 


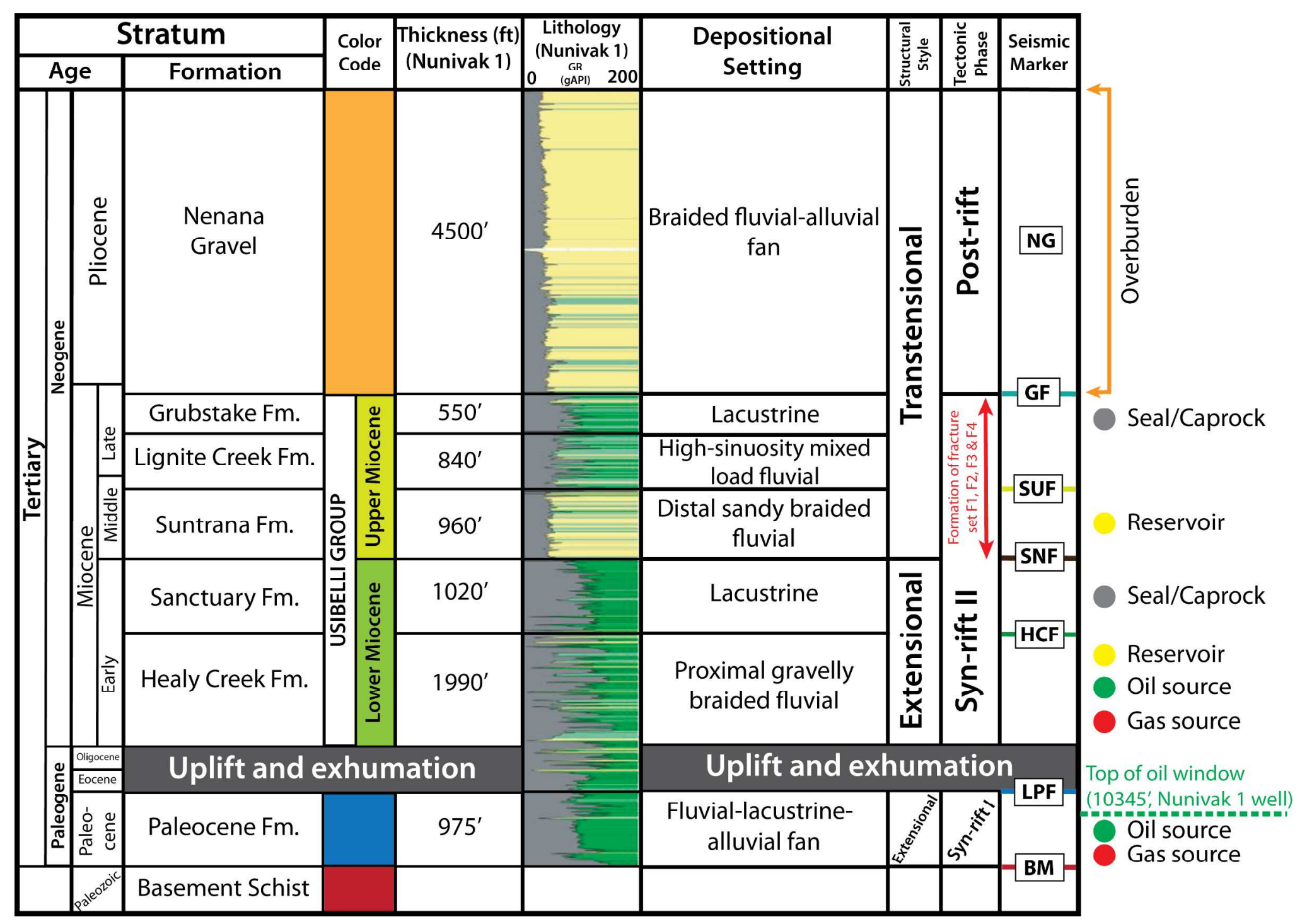




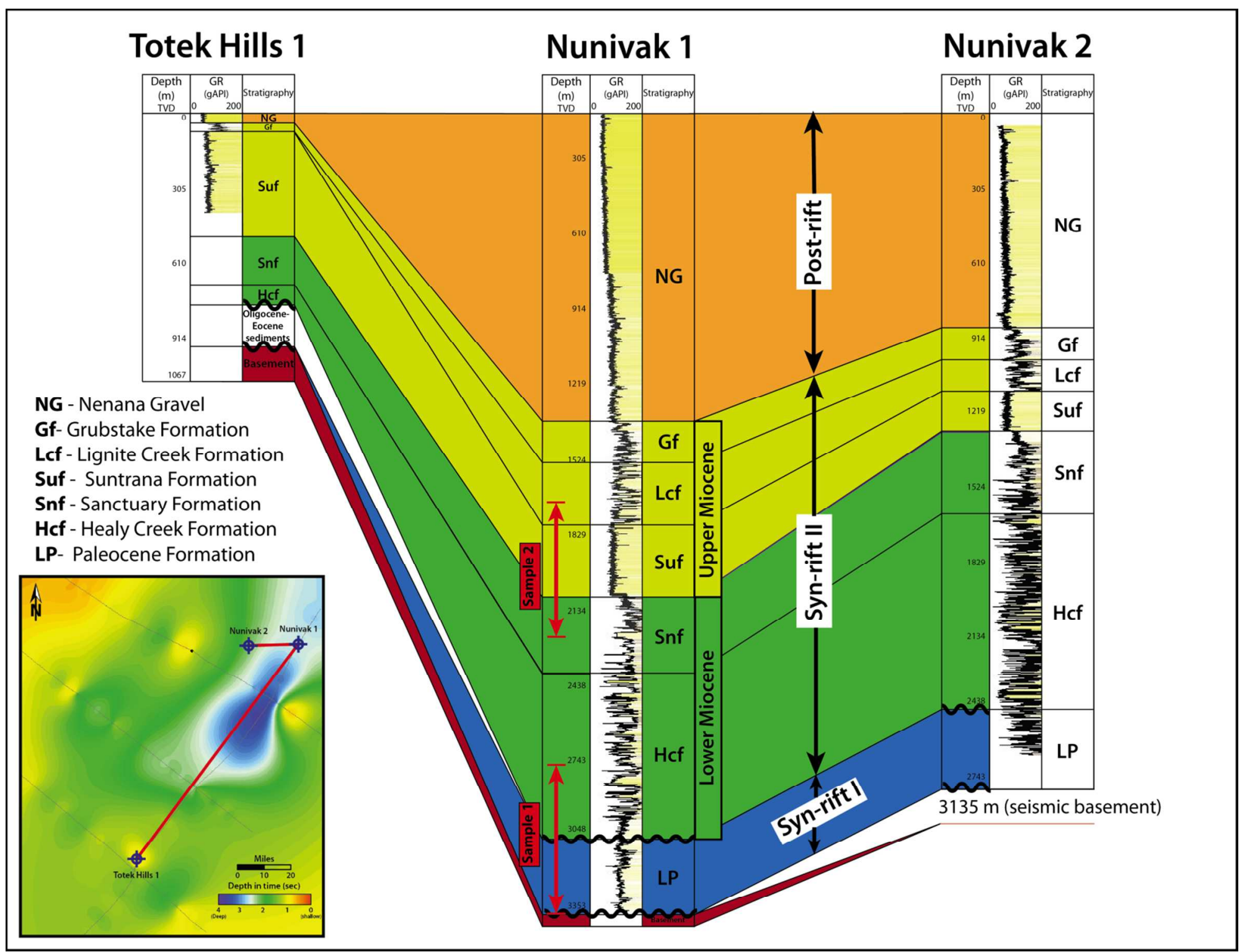




\section{Seismic profile TA-02}

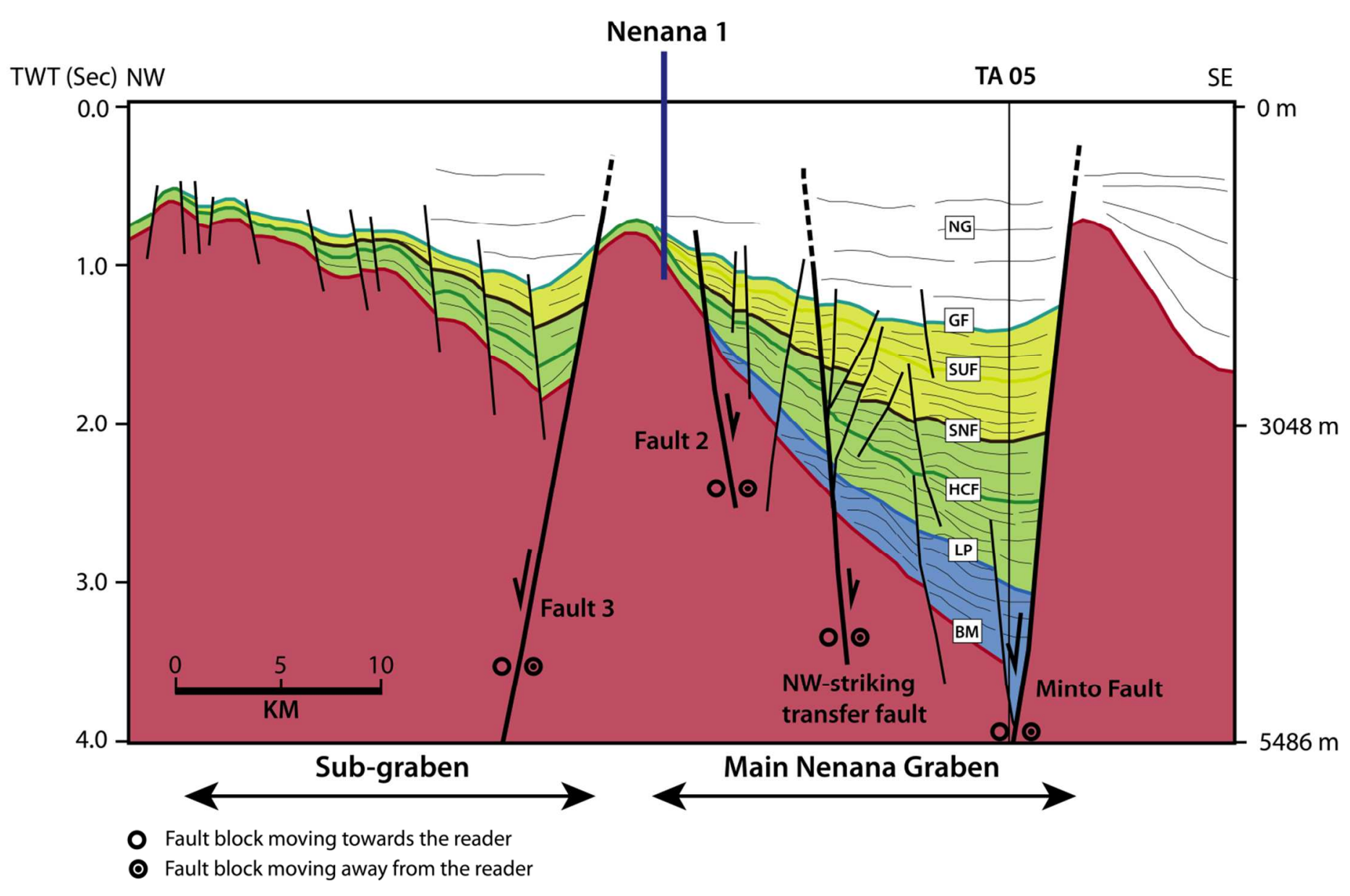




\section{Seismic profile TA-05}

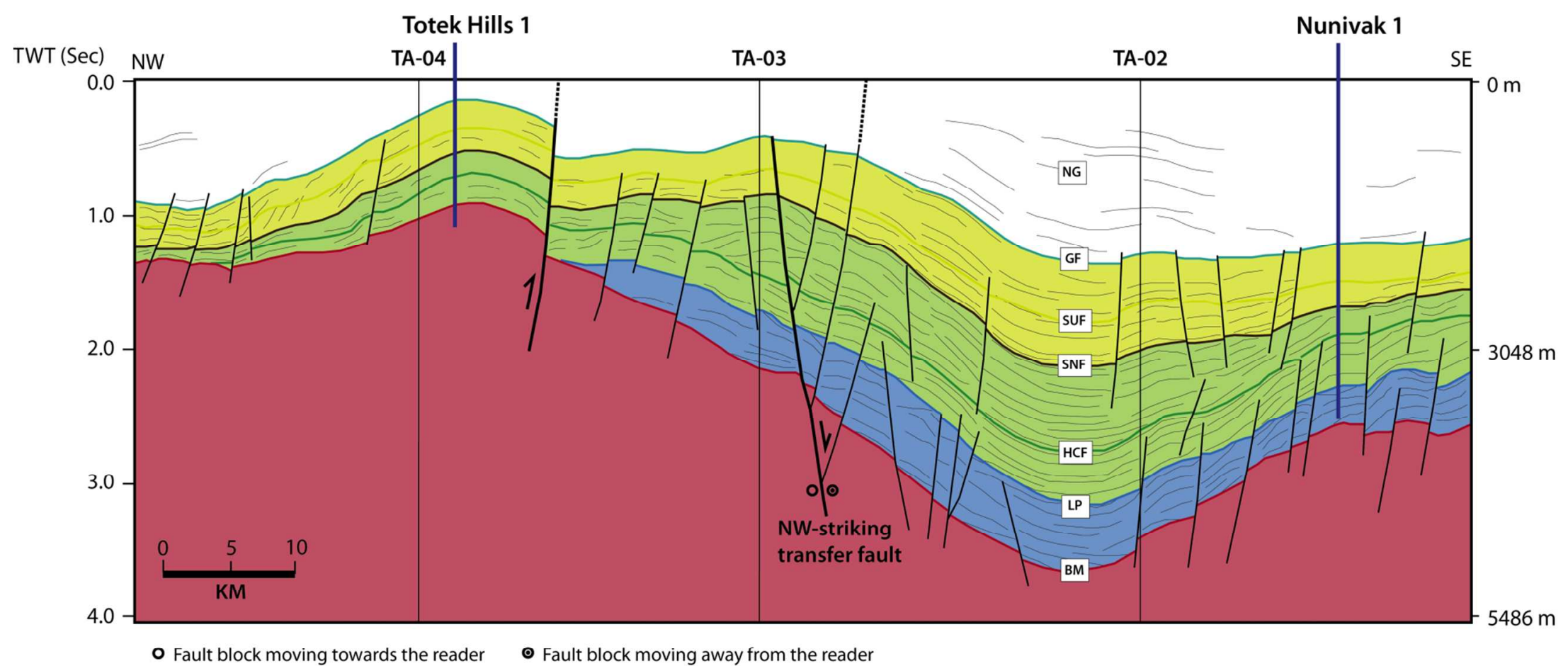




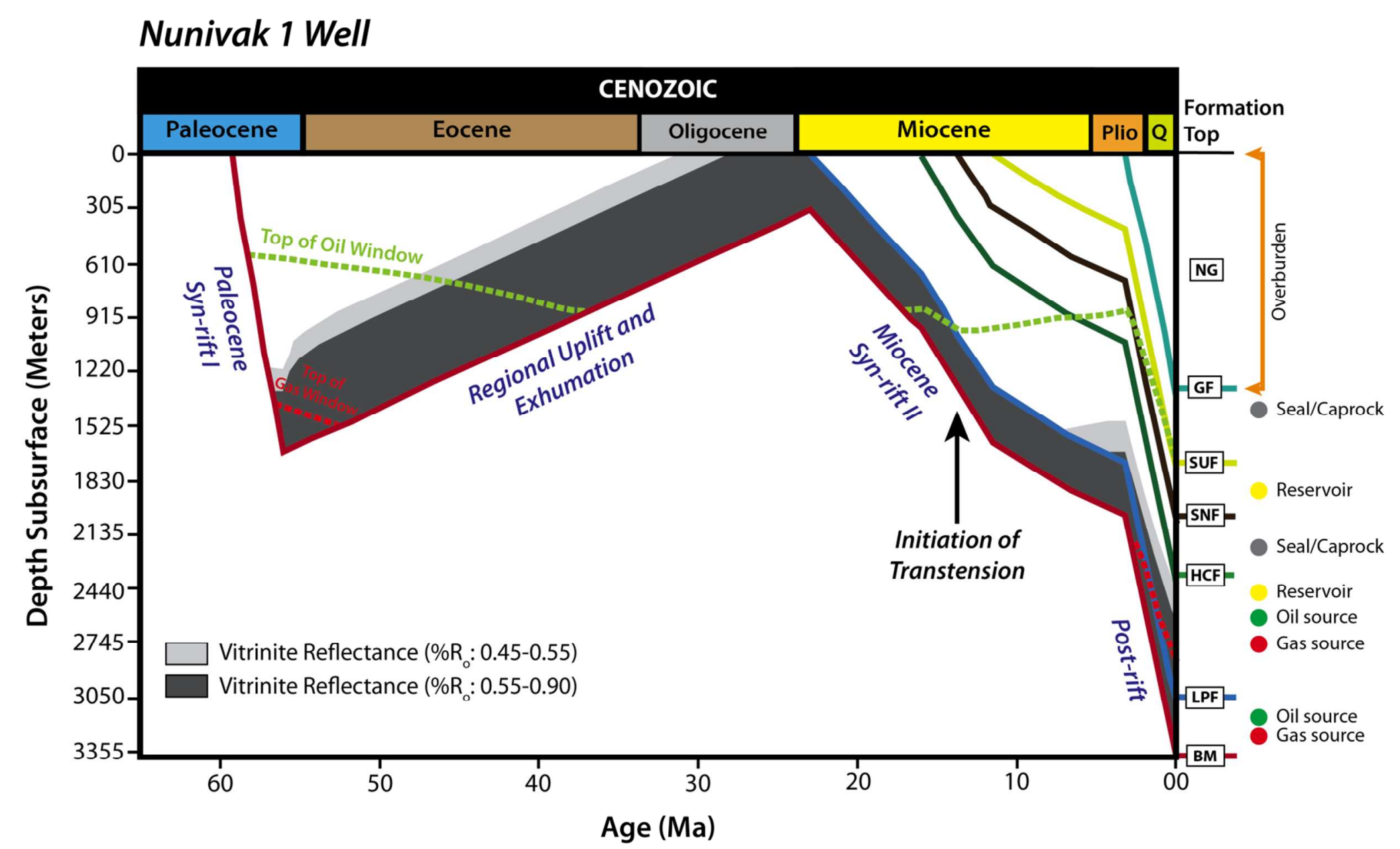

BM - Basement LPF- Paleocene Fm. HCF - Healy Creek Fm. SNF - Sanctuary Fm. SUF - Suntrana Fm. GF- Grubstake Fm. NG - Nenana Gravel 


\section{Apatite Samples from Nunivak 1 Well}
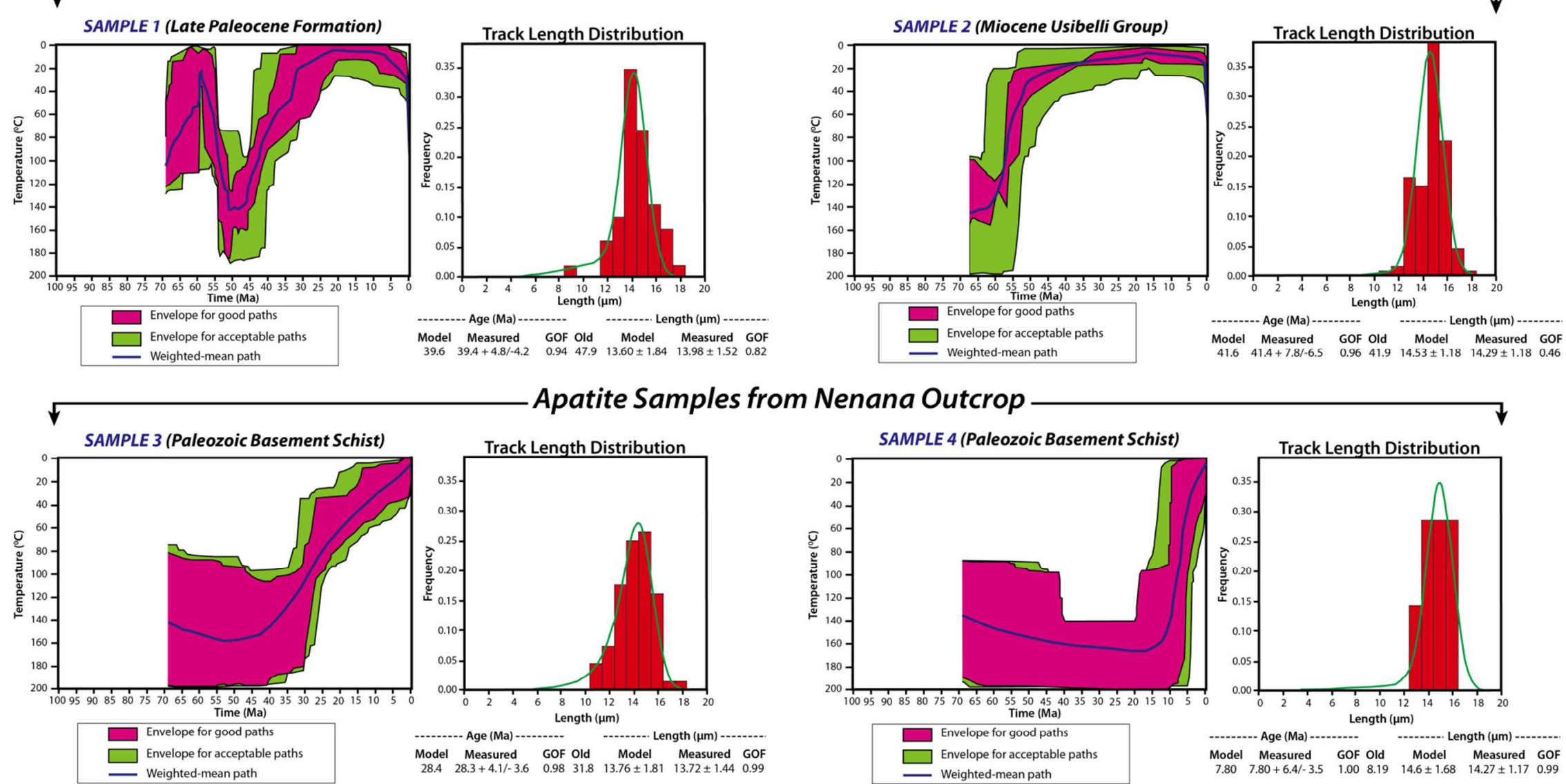

\section{Apatite Samples from Nenana Outcrop}
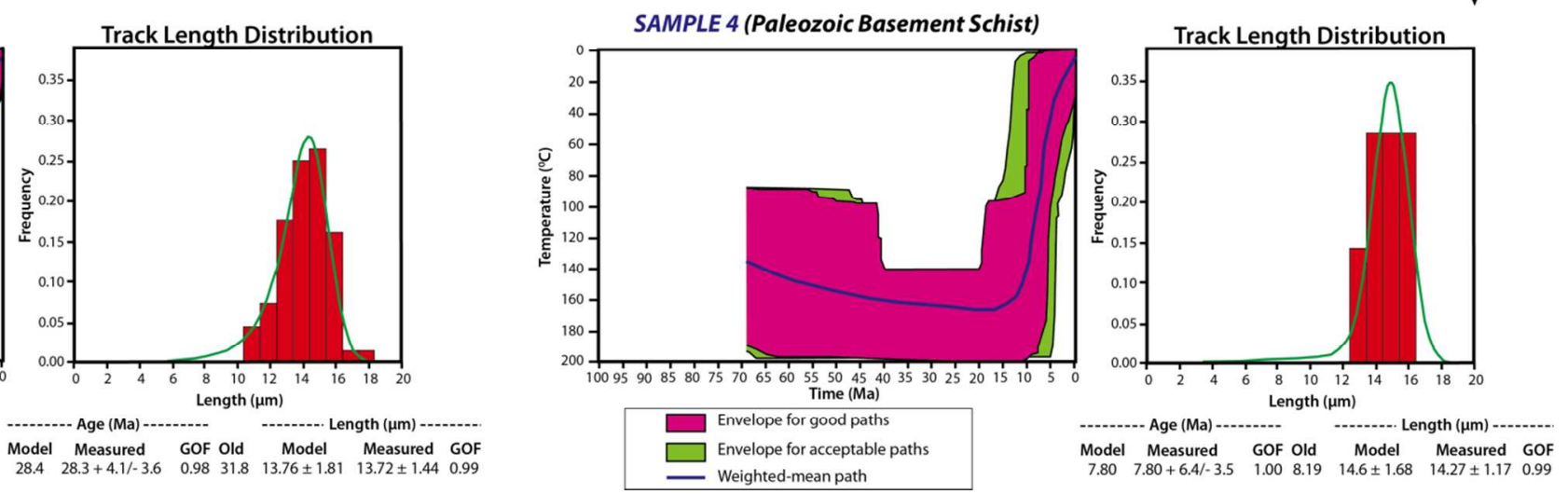

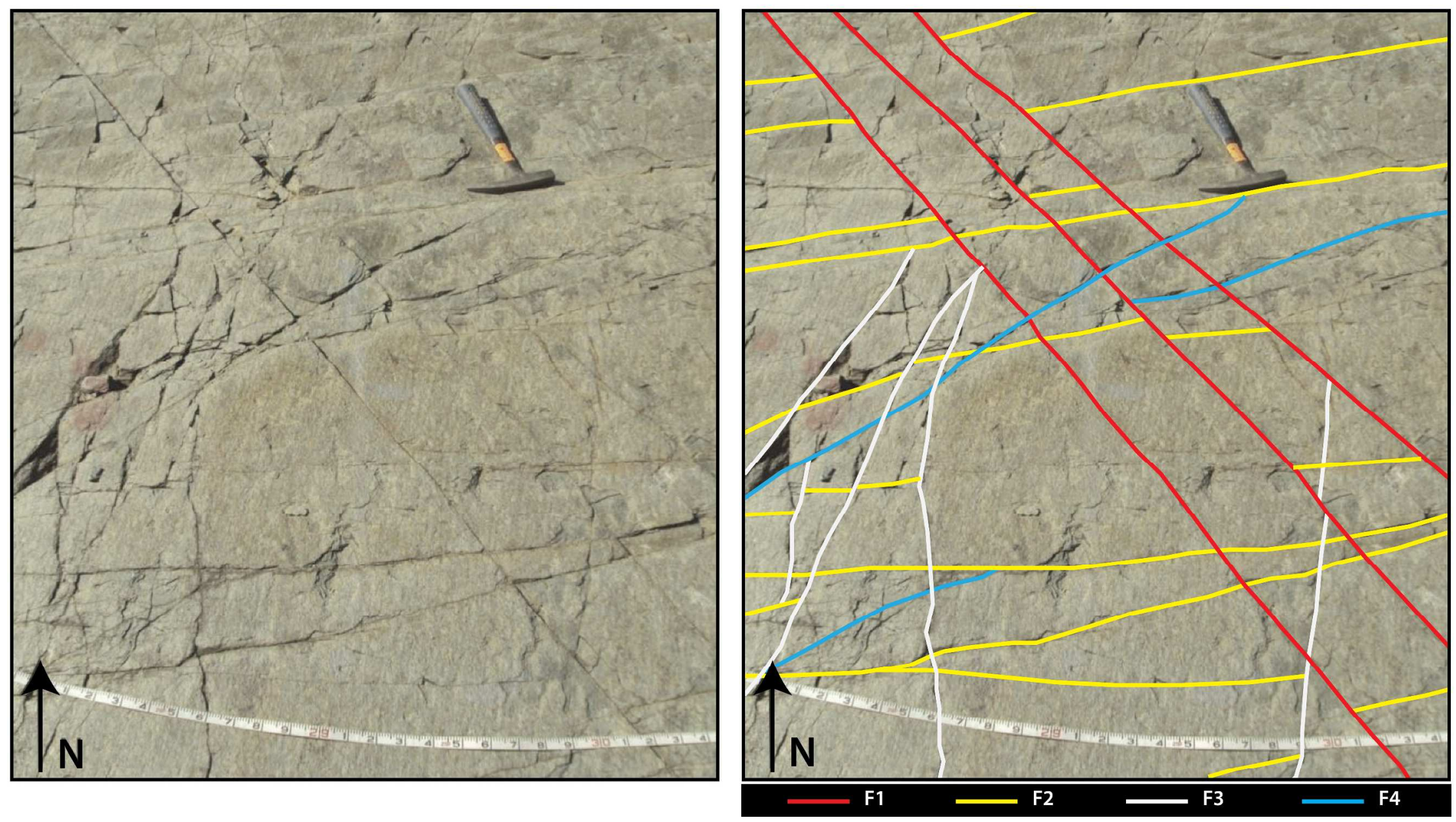


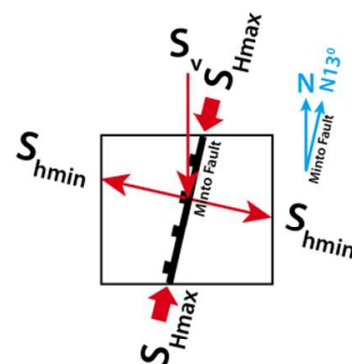

Normal faulting

$\left(\mathrm{S}_{\mathrm{v}}>\mathrm{S}_{\mathrm{H} \max }>\mathrm{S}_{\mathrm{hmin}}\right)$
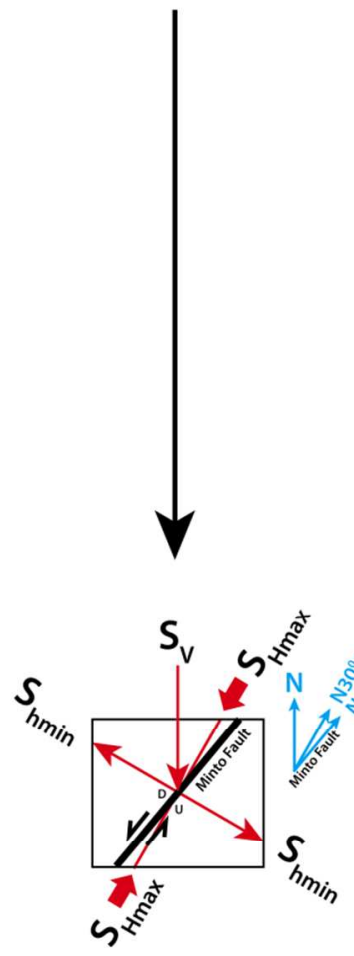

Strike-slip faulting

$\left(\mathrm{S}_{\text {Hmax }}>\mathrm{S}_{\mathrm{v}}>\mathrm{S}_{\mathrm{hmin}}\right)$
(A) Late Paleocene-Early Eocene Initiation of Graben System

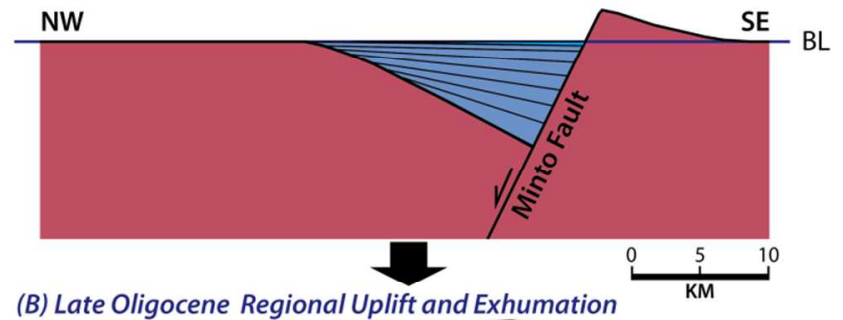

(B) Late Oligocene Regional Uplift and Exhumation

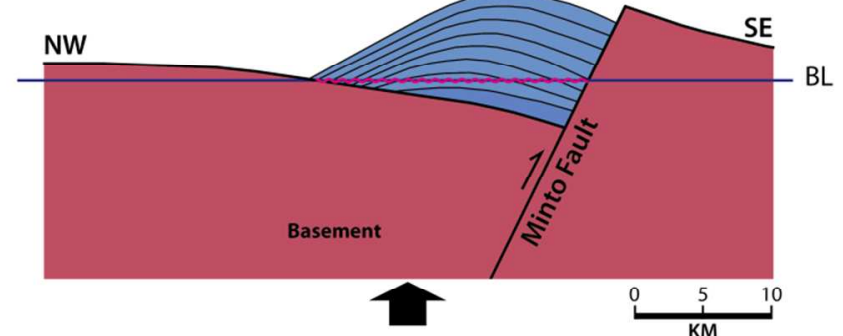

(C) Late Miocene Extensional to Transtensional Regime

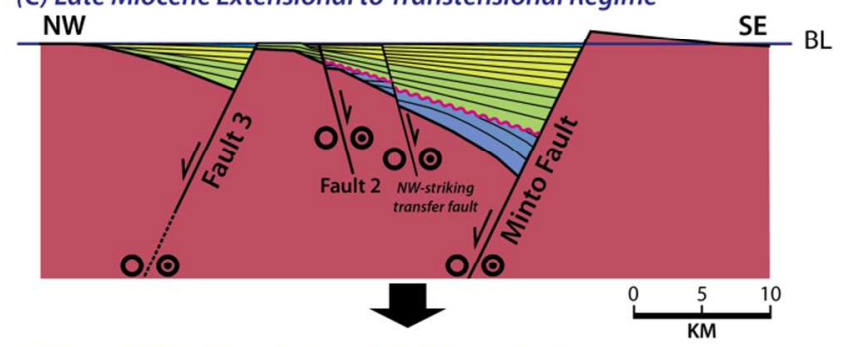

(D)Present-Day Transtensional Pull-Apart Basin

\section{NW}

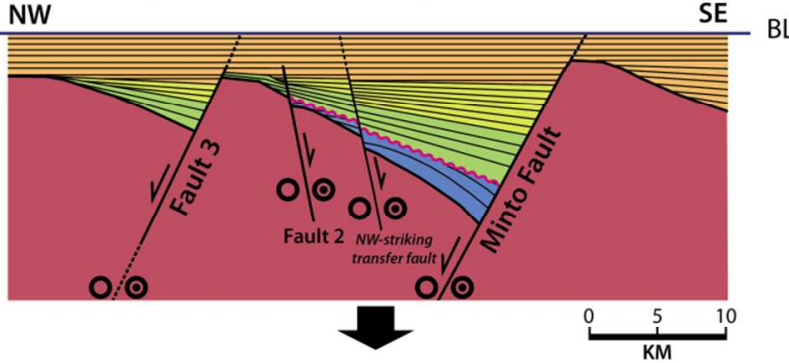

Legend

Nenana Gravel

Upper Miocene Sequence

Lower Miocene Sequence

Late Paleocene Formation

Basement

Basinal subsidence/uplift

- Fault block movement towards the reader

- Fault block movement away from the reader

BL Base Level

$\mathrm{S}_{v} \quad$ vertical or overburden stress

$\mathrm{S}_{\mathrm{H} \max }$ Maximum horizontal stress

$\mathrm{S}_{\mathrm{hmin}}$ Minimum horizontal stress 


\section{Time-temperature path for the fracture area (Sample 4)}

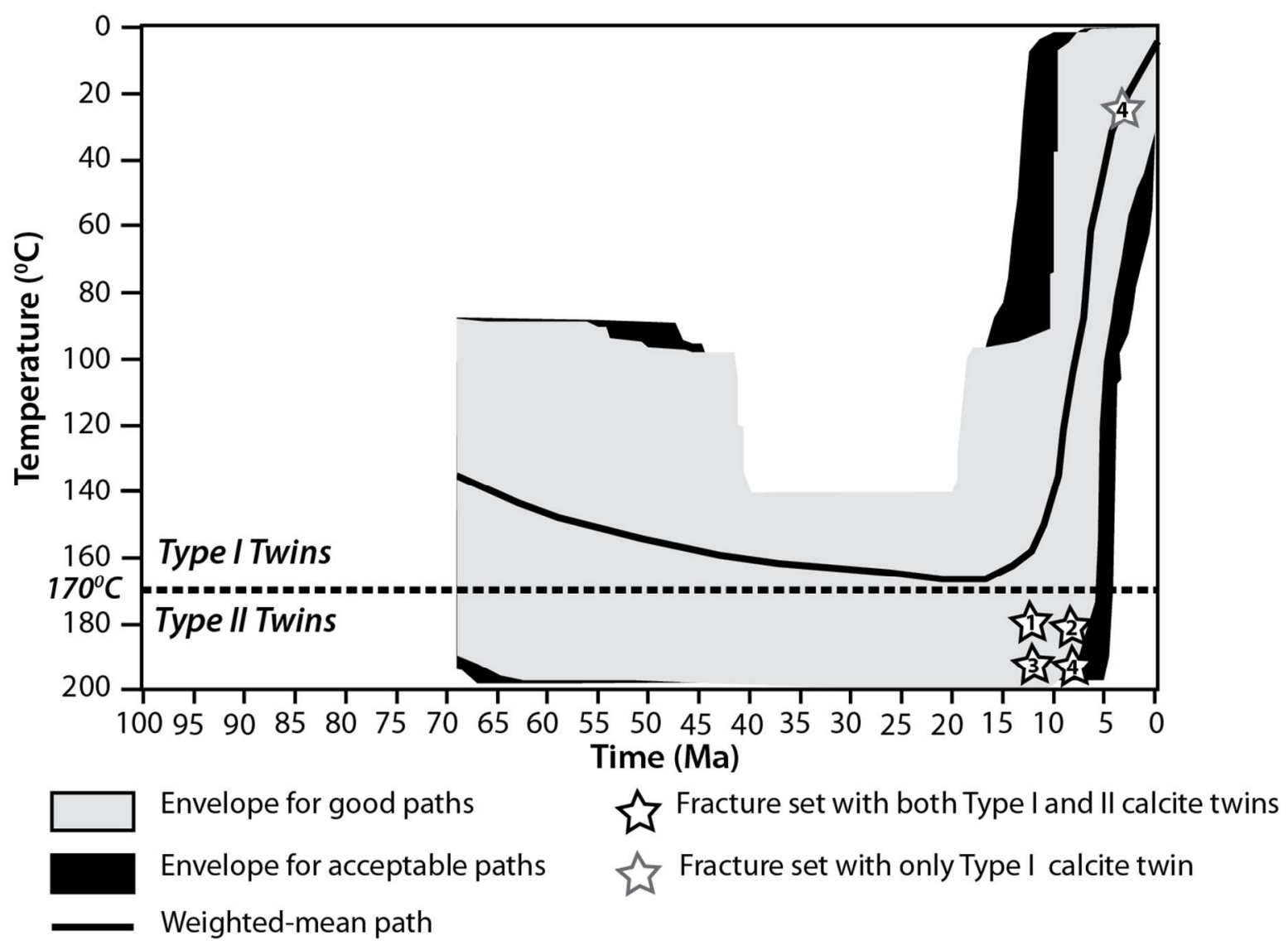

